\title{
KOMPARASI PERANG PROFIL TIGA KANDIDAT PRESIDEN PADA PEMILU 2009 (Analisis Wacana Pada Harian Kompas)
}

\author{
Sholihul Huda dan Ali Nurdin \\ Sholihul Huda, Mahasiswa Program Studi Ilmu Komunikasi Fakultas Dakwah \\ IAIN Sunan Ampel Surabaya Angkatan 2006, sekarang bekerja di Metro \\ TV Jawa Timur. \\ Ali Nurdin, Dosen Tetap Program Studi Ilmu Komunikasi Fakultas \\ Dakwah \\ IAIN Sunan Ampel Surabaya
}

\begin{abstract}
Abstraksi
Pemilihan presiden (pemilu) pada tahun 2009 oleh harian Kompas dijadikan lahan dalam memperkaya citra dalam pemberitaan, Kompas mampu menghadirkan profil kandidat presiden sebagai sarana menyebarkan ideologinya. Penelitian ini membahas tentang peran Kompas dalam meramaikan demokratisasi di Indonesia. Kompas ternyata bukan sekedar memberitakan (merepresentasikan) peristiwa dan para elit politik dalam pemilihan presiden saja. Ada kecenderungan Kompas melakukan konstruksi realitas atas peristiwa dan kandidat presiden yang terlibat dalam sebuah pemilihan presiden.

Penelitian ini menggunakan metode analisis wacana model Teun A. Van Dijk. Penelitian ini mencoba untuk mengungkap makna dibalik tabir teks yang dikonstruksi oleh Harian Kompas. Kandidat presiden yang akan bertarung pada pemilihan presiden pada tanggal 8 Juli 2009 adalah Megawati Soekarnoputri, Susilo Bambang Yodhoyono, dan Moh. Jusuf Kalla. Dari hasil deskripsi, diketahui banyak temuan yang menyatakan bahwa, keberpihakan Kompas dalam memberitakan profil SBY sangat kelihatan. Tulisan mengarah kepada penjatuhan citra kandidat presiden Megawati, melalui track record yang negatif. Begitu pula dengan kandidat presiden JK yang mempunyai julukan the real president, tidak mampu mengalahkan kehebatan SBY. Wartawan tidak sedikitpun membandingkan kepintaran JK dalam memimpin dengan kandidat SBY.
\end{abstract}

Kata Kunci: Komparasi Perang Profil, Tiga Kandidat Presiden Pada Pemilu 2009 


\section{Pendahuluan}

Pemilihan presiden pada tahun 2009 merupakan peristiwa PEMILU yang sangat kompetitif, dikarenakan kandidat-kandidatnya sudah tidak asing dalam panggung politik nasional. Ada tiga kandidat yang memperebutkan kursi kepresidenan. Mereka antara lain : Pertama, mantan presiden Indonesia ke-5, Megawati Soekarnoputri. Kedua,wakil presiden 2004-2009, Moh. Jusuf Kalla. Ketiga, Presiden incumbent Susilo Bambang Yudhoyono. Mereka yang bertarung mulai mengepakkan sayap dalam mencari pendukung sebanyakbanyaknya, melalui berbagai cara, terutama di media massa.

Pada pemilihan presiden ini, media dengan gencar dan semangat memberitakan berbagai macam peristiwa dari fenomena pelaksanaan pemilihan presiden tersebut. Bagi rakyat Indonesia fenomena seperti ini sudah tidak asing lagi, karena pelaksanaan pemilihan presiden sudah pernah dialami pada tahun 2004 silam, dan menyimpan pengalaman serta kesan tersendiri bagi rakyat Indonesia.

Bermula dari fenomena itu, media menurut Edmund Burke ${ }^{1}$, merupakan pilar ke-empat dalam demokrasi, juga tidak mau ketinggalan dalam menampilkan dan memberitakan peristiwa-peristiwa yang dianggapnya penting untuk dipublikasikan. Berfokus pada media cetak, surat kabar yang sudah mapan memiliki halaman yang diperuntukkan khusus untuk laporan pemilihan termasuk juga kampanye ${ }^{2}$. Misalnya Kompas pada periode pemilihan 2009, mengkhususkan halaman 33-42 yang mengulas tentang profil tiga kandidat presiden dan wakil presiden selama tiga hari berturut-turut, dari tanggal 29, 30 Juni 2009 sampai 1 Juli 2009, dengan tema edisi spesial pemilihan presiden.

Dalam pemberitaan tersebut, terdapat konstruksi wacana yang akan melahirkan banyak persepsi dan pengaruh besar bagi pembaca. Wacanawacana dalam pemilihan presiden nampak kuat pada perwajahan beberapa halaman di harian kompas yang ada pada rubrik kandidat yang mengulas profil dari kandidat-kandidat presiden. Dari ketiga calon presiden yang diberitakan profil-nya tersebut, terdapat perbedaan dalam pemaparan dan penggunaan space atau halaman yang diberikan.

Berdasarkan pemikiran di atas maka penelitian ini menggunakan analisis wacana kritis (Critical Discourse Analiysis). Analisis wacana kritis memandang wacana bahasa yang digunakan dalam tuturan dan tulisan sebagai bentuk 'praktik sosial'. Dengan menggambarkan wacana sebagai praktik sosial

\footnotetext{
${ }^{1}$ Moh Amien Rais, Agenda Mendesak Bangsa: Selamatkan Indonesia, (Yogjakarta:PPSK Press, 2008), hal. 115

2 Pawito, Komunikasi Politik: Media Massa dan Kampanye Pemilihan, (Yogyakarta: Jalasutra, 2009), hal 175
}

Jurnal Ilmu Komunikasi, Vol. 1, No.1, April 2011

ISSN: 2088-981X 
menyiratkan adanya hubungan dialektik antara sebuah peristiwa diskursif tertentu dengan situasi, institusi, dan struktur sosial yang mewadahinya ${ }^{3}$. Teun A. Van Dijk yang memandang wacana umumnya sebagai teks dalam konteks dan sebagai bukti yang harus diuraikan secara empiris ${ }^{4}$, menjadikan hal tersebut sangat perlu dikaji guna mendapatkan tambahan pemahaman pembaca.

Teun A. Van Dijk melihat suatu teks terdiri atas beberapa struktur atau tingkatan yang masing-masing bagian saling mendukung, ia membaginya ke dalam tiga tingkatan ${ }^{5}$. Pertama, Struktur Makro. Ini merupakan makna global atau umum dari suatu teks yang dapat diamati dengan melihat topik atau tema yang dikedepankan atas suatu berita, struktur itu adalah Tematik. Kedua, Superstruktur. Ini merupakan struktur wacana yang berhubungan dengan kerangka suatu teks, bagaimana bagian-bagian teks tersusun ke dalam berita secara utuh, dan yang termasuk ke dalam struktur ini adalah Skematik. Yang ketiga adalah Struktur Mikro. Ini merupakan makna wacana yang dapat diamati dari bagian kecil dari suatu teks yakni kata, kalimat, proposisi, anak kalimat, paraphrase, dan gambar, struktur ini meliputi Semantik, Sintaksis, Stilistik, dan Retoris. Van Dijk mencoba untuk menguraikan praktik-praktik sosial yang dibungkus oleh media lewat sebuah wacana. Hal ini menjadi sangat penting dan juga menarik ketika dilihat dari kacamata penelitian yang akan melihat dan menganalisis isi wacana-wacana menjadi sebuah kerangka pemahaman yang berbeda. Van Dijk meng-elaborasi elemen-elemen wacana sehingga bisa didayagunakan dan dipakai secara praktis ${ }^{6}$.

\section{Rumusan Masalah}

Dari konteks latar belakang masalah di atas, penulis membatasi penelitian ini dalam beberapa hal. Pertama, secara substansi penelitian ini dilakukan terhadap teks berita sebagai wacana yang dikonstruksi oleh harian Kompas. Kedua, secara metodologi penelitian ini difokuskan pada teks berita yang berkaitan dengan pemberitaan profil tiga kandidat presiden pada Pemilihan Umum 2009 di Kompas. Maka untuk itu penulis merumuskan masalah sebagai berikut :

1. Bagaimana Struktur Makro di Harian Kompas dalam pemberitaan Profil Tiga Kandidat Presiden pada Pemilihan Umum 2009 ?

\footnotetext{
${ }^{3}$ Stefan Titscher dkk, Metode Analisis Teks dan Wacana, Terjemahan oleh Gazali,Thomas Pandonge dkk, (Yogyakarta: Pustaka Pelajar, 2009), hal. 44

${ }^{4}$ Ibid, hal. 43

${ }^{55}$ Eriyanto, Analisis Wacana:Pengantar Analisis Teks Media, (Yogyakarta: Lkis, 2006), hal. 226

${ }^{6}$ Ibid, hal. 221
}

Jurnal Ilmu Komunikasi, Vol. 1, No.1, April 2011

ISSN: 2088-981X 
2. Bagaimana Superstruktur di Harian Kompas dalam pemberitaan Profil Tiga Kandidat Presiden pada Pemilihan Umum 2009?

3. Bagaimana Struktur Mikro di Harian Kompas dalam pemberitaan Profil Tiga Kandidat Presiden pada Pemilihan Umum 2009?

4. Bagaimana perbandingan penyajian dari ketiga isi wacana dalam pemberitaan Profil Tiga Kandidat Presiden pada Harian Kompas?

\section{Tujuan Penelitian}

Dari uraian rumusan masalah di atas, penulis dapat menentukan tujuan penelitian sebagai berikut:

1. Untuk dapat mendiskripsikan Struktur Makro di Harian Kompas dalam pemberitaan Profil Tiga Kandidat Presiden pada Pemilihan Umum 2009

2. Untuk dapat mendiskripsikan Superstruktur di Harian Kompas dalam pemberitaan Profil Tiga Kandidat Presiden pada Pemilihan Umum 2009

3. Untuk dapat mendiskripsikan Struktur Mikro di Harian Kompas dalam pemberitaan Profil Tiga Kandidat Presiden pada Pemilihan Umum 2009

4. Mengetahui perbandingan penyajian berita dari Ketiga Profil Kandidat Presiden pada Pemilihan Umum 2009 di Harian Kompas.

\section{Tinjauan Teoritis}

Demokrasi adalah praktik politik. Sedangkan politik, seperti dikatakan Harold D. Lasswell ${ }^{7}$ adalah "siapa mendapatkan apa, kapan, dengan cara bagaimana (who gets what, when, how). Dalam definisi ini, who atau siapa adalah aktor politik seperti pengurus partai, anggota parlemen, presiden, aktivis, dan lainnya dari mereka yang bergulat dalam bidang politik. Ketika berpolitik, para aktor politik bermaksud mendapatkan sesuatu (gets what) entah itu perolehan materi maupun non-materi seperti kedudukan dan jabatan dan tentu saja kekuasaan. Pada dasarnya aktor politik setiap saat (when) berpolitik bukan hanya pada musim pemilihan umum sebagai salah satu ikon demokrasi. Para aktor politik menggunakan setiap kesempatan untuk memperoleh keuntungankeuntungan politik mereka.

Dalam pandangan komunikasi, juga dalam asas demokrasi, salah satu cara (how) aktor politik (who) untuk memperoleh sesuatu (gets what) itu adalah dengan cara berkomunikasi. Ini sejalan dengan salah satu definisi politik yang dikemukakan oleh Mark Roelofs ${ }^{8}$, yang mengatakan: Politics is talks... the activity

\footnotetext{
7 Ibnu Hamad, Media dan Demokrasi di Asia Tenggara: Kasus Indonesia, Universitas Indonesia, (online) di akses pada 25 November 2009, (jati.um.edu.my/iconsea2007/download/paper/ibnuhamadb.pdf ). hal. 1

8 Ibid. hal 2
} 
of politics ('politicking") is talking berpolitik adalah berbicara, yang berarti berpolitik tidak lain adalah berkomunikasi. Tentu saja yang dimaksud komunikasi itu bisa mengunakan media massa (koran, majalah, tabloid, radio, tv, film) maupun non-media massa (surat, leaflet, booklet, spanduk, baligo, internet, saluran komunikasi interpersonal, saluran komunikasi kelompok dan organisasi serta jaringan komunikasi). Dalam praktik, seorang aktor politik dapat mendayagunakan secara tumpang tindih saluran-saluran komunikasi tersebut. Sekalipun media massa seperti surat kabar, majalah, radio, dan TV bukan satu satunya saluran komunikasi politik, akhir-akhir ini di berbagai belahan dunia termasuk Indonesia, peranan media sangat penting dalam kehidupan politik.

Dalam komunikasi politik, kontruksi realitas oleh media massa tersebut menjadi sangat khas. Sebab cara sebuah media mengkonstruksikan suatu peristiwa politik akan memberi citra tertentu tentang peristiwa atau aktor politik itu. Karena itulah para aktor politik sangat berkepentingan untuk membangun hubungan baik dengan para wartawan (press relation) dan berbagai media (media relation). Bagaimana persisnya media massa mengkonstruksikan realitas politik. Sederhananya, proses konstruksi realitas adalah upaya "menceritakan" (koseptualisasi) sebuah peristiwa, keadaan, orang atau benda tak terkecuali mengenai hal-hal yang berkaitan dengan politik. Bahkan karena sifat dan faktanya bahwa pekerjaan media massa adalah menceritakan peristiwaperistiwa, maka seluruh isi media tiada lain adalah realitas yang telah dikonstruksikan (constructed reality) sedemikian rupa susunannya hingga membentuk sebuah cerita atau wacana yang bermakna.

Dalam konstruksi realitas, bahasa adalah unsur utama. Ia merupakan instrumen pokok untuk menceritakan realitas. Bahasa adalah alat konseptualisasi dan alat narasi. Begitu pentingnya bahasa, maka tak ada berita, cerita, ataupun ilmu pengetahuan tanpa bahasa. Dalam filsafat bahasa dikatakan bahwa orang menciptakan realitas menatanya lewat sebuah bahasa. Seperti ungkapan Lorens Bagus $^{9}$, bahasa mengangkat ke permukaan hal yang tersembunyi sehingga menjadi kenyataan.

Selanjutnya, penggunaan bahasa (simbol) tertentu menentukan format narasi (dan makna) tertentu. Sedangkan jika dicermati secara teliti, seluruh isi media entah media cetak ataupun media elektronik adalah bahasa, baik bahasa verbal (kata-kata tertulis atau lisan) maupun bahasa non-verbal (gambar, photo, gerak-gerik, grafik, angka, dan tabel). Lebih jauh dari itu, terutama dalam media massa, keberadaan bahasa ini tidak lagi sebagai alat semata untuk

\footnotetext{
${ }^{9}$ Alex Sobur, Analisis Teks Media: Suatu Pengantar untuk Analisis Wacana, Analisis Semiotik, dan Analisis Framing, (Bandung: PT. Remaja Rosda Karya, 2006), Cetekan Keempat April 2006, hal 16
} 
menggambarkan sebuah realitas, melainkan bisa menentukan gambaran (citra) mengenai suatu realitas-realitas media yang akan muncul di benak khalayak.

Disamping penggunaan bahasa (simbol politik), media juga melakukan strategi pembingkaian (framing strategy). Di sini media massa mengemas (packaging) realitas ke dalam sebuah struktur tertentu sehingga isu sebuah mempunyai makna tertentu. Hal ini terjadi karena dalam proses pengemasan berlangsung proses memilih fakta atas dasar frame tertentu sehingga ada fakta yang ditonjolkan, disembunyikan, bahkan dihilangkan dari narasi (berita) yang akan dibentuk. Alhasil, dilihat dari strategi framing ini, setiap berita politik selalu memiliki struktur internalnya sendiri yakni gagasan inti (acentral organizing ide) yang dibingkai dalam sebuah struktur tertentu.

Untuk lebih mengenali dan mendalami peranan media pada demokrasi, maka petutlah kita ketahui bersama artikel dari John Lioyd, sebagai pegangan dalam menyelami pertautan demokrasi dengan media massa. Inilah sedikit kutipan artikelnya yang berbunyi:

"Menegaskan bahwa politik di banyak negara tidak bisa terlepas dari eksistensi sorotan media, karena media diyakini menjadi salah satu tonggak penegakan demokrasi. Terkait dengan hal ini, peran media nampak semakin dominan, tidak hanya media cetak tetapi juga visual dan utamanya adalah media online. Oleh karena tantangan kode etik jurnalistik ini, maka peliput media selalu berbenturan dengan banyak kepentingan, termasuk kepentingan untuk meliput berbagai kasus mega-skandal yang tentunya ini terkait juga dengan sejumlah pejabat, petinggi, saudara dari pejabat, petinggi dan atau mungkin anak-anak dari pejabat dan petinggi. Di satu sisi, pemberitaan yang diekspose media tentu telah melalui prosedur jurnalistik yang sistematis, bukan sekadar bombastis sebab taruhan bagi media adalah adanya hak jawab dari pihak yang merasa dirugikan dari pemberitaan yang ada. Adanya dua kepentingan yang berbeda inilah yang akhirnya memicu niat-niat busuk dari segelintir oknum untuk menggunakan kekerasan demi menuntaskan keinginan agar apa yang diberitakan tidak semakin heboh diungkit media $10 "$

\section{Metode Penelitian}

Penelitian ini menggunakan pendekatan konstruktivisme atau pendekatan kritis dengan menggunakan jenis penelitian Analisis Teks Wacana model Teun A. Van Dijk. Obyek yang akan dianalisis adalah teks berita pada rubrik kandidat yang memuat tentang pemberitaan Profil Tiga Kandidat Presiden pada Pemilihan Umum 2009 di Harian Kompas edisi 29, 30 Juni 2009 dan 1 Juli 2009.

${ }^{10}$ http://bataviase.co.id/detailberita-10332406.html di akses pada tanggal 7 Desember 2009 
Sumber data dalam penelitian ini adalah hasil dokumentasi yang menitikberatkan pada Koran Harian Kompas tentang pemberitaan Profil Tiga Kandidat Presiden pada Pemilihan Umum 2009. Teknik pengumpulan data dalam penelitian ini menggunakan teknik dokumentasi yaitu dengan mencari dan membaca dari beberapa referensi yang ada. khususnya pada Harian Kompas edisi 29, 30 Juni 2009 dan 1 Juli 2009 sebagai data utama penelitian ini.

Analisis data dalam penelitian ini menggunakan desain operasional analisis wacana model Teun A. Van Dijk ditambah dengan beberapa teori yang mendukung dan relevan sebagaimana pada tabel sebagai berikut:

Tabel 1

Struktur Wacana Teun A. Van Dijk ${ }^{11}$

Struktur Makro

Makna global dari suatu teks yang dapat diamati dari topik atau tema yang diangkat oleh teks.

\begin{tabular}{|c|c|c|}
\hline \multicolumn{3}{|c|}{$\begin{array}{c}\text { Super Struktur } \\
\text { Kerangka suatu teks, seperti bagian pendahuluan, isi, penutup dan kesimpulan }\end{array}$} \\
\hline \multicolumn{3}{|c|}{$\begin{array}{c}\text { Struktur Mikro } \\
\text { Makna local dari suatu teks yang dapat diamati dari pilihan kata, kalimat dan gaya yang dipakai } \\
\text { oleh satu teks }\end{array}$} \\
\hline \multicolumn{3}{|c|}{$\begin{array}{l}\text { Tabel } 2 \\
\text { ruktur Wacana Teun A. Van Dijk }\end{array}$} \\
\hline Struktur Wacana & Hal Yang Diamati & Elemen \\
\hline Struktur Makro & $\begin{array}{c}\text { TEMATIK } \\
\text { (Apa yang dikatakan ?) }\end{array}$ & Topik \\
\hline Superstruktur & $\begin{array}{l}\text { SKEMATIK } \\
\text { (Bagaimana pendapat disusun } \\
\text { dan dirangkai) }\end{array}$ & Skema \\
\hline Struktur Mikro & $\begin{array}{l}\text { SEMANTIK } \\
\text { (Makna yang ingin ditekankan } \\
\text { dalam teks berita) }\end{array}$ & $\begin{array}{l}\text { Latar, Detail, Maksud, Pra- } \\
\text { anggapan, Nominalisasi }\end{array}$ \\
\hline Struktur Mikro & $\begin{array}{l}\text { SINTAKSIS } \\
\text { (Bagaimana pendapat } \\
\text { disampaikan ) }\end{array}$ & $\begin{array}{l}\text { Bentuk Kalimat, koherensi, } \\
\text { Kata ganti }\end{array}$ \\
\hline Struktur Mikro & $\begin{array}{c}\text { STILISTIK } \\
\text { (Pilihan kata apa yang dipakai) }\end{array}$ & Leksikon \\
\hline Struktur Mikro & $\begin{array}{l}\text { RETORIS } \\
\text { (Bagaimana dan dengan cara } \\
\text { apa penekanan dilakukan) }\end{array}$ & Grafis, Metafora, Ekspresi \\
\hline
\end{tabular}

\footnotetext{
${ }^{11}$ Eriyanto, 2006, Analisis Wacana : Pengantar Analisis Teks ............hal, 227
} 


\title{
Pembahasan Hasil Penelitian
}

\section{Konstruksi Wacana Harian Kompas Edisi 29 Juni 2009 (Kandidat Presiden Megawati Soekarnoputri)}

Tabel 3

\author{
a. Judul: Megawati Soekarnoputri: Menyusun Pertarungan dari Bawah \\ (Penulis: Myrna Ratna dan Agus Hermawan) \\ Tingkatan \& \\ Strategi Penulisan
}

Elemen

(Stuktur Makro) Judul: Megawati Soekarnoputri: Menyusun Pertarungan dari Bawah

Tematik (Font judul: menggunakan capital semua dan berwarna merah sesuai dengan warna partai pengusungnya - PDI-Perjuangan)

(Superstuktur) Bentuk tulisan balok tegak, yaitu inti berita menyebar di semua Skematik tulisan.

Summary: Drama politik paling menarik selama gonjang-ganjing koalisi pasca Pemilihan Umum Lagislatif 2009 adalah ketika Partai Demokrat secara terbuka menawarkan koalisi kepada Partai Demokrasi Indonesia perjuangan. (lead)

Diawali dengan kedatangan Menteri Sekretaris Negara Hatta Rajasa ke kediaman Megawati Soekarnoputri pada 6 Mei 2009, sinyal itu kemudian diperkuat dengan pernyataan Susilo Bambang Yudhoyono bahwa "ada kehendak kedua partai untuk melakukan rekonsiliasi melalui komunikasi politik". (sub lead)

Sub judul : Kembali bertarung

Story: Bukan, bukan itu, katanya. Berkali-kali Mega menuturkan bahwa ia ingin menuntaskan sejumlah agenda kerja yang belum sempat diwujudkannya dalam pemerintahannya yang hanya berlangsung 2,5 tahun. (Paragraf ke-2)

Sub Judul: Tabel kekayaan dan utang (Tabel ini menjelaskan tentang kekayaan dan utang Megawati)

(Stuktur Mikro) Namun, kalkulasi politik semata tidak selalu pas bila di terapkan pada Semantik

Latar sosok Dyah Permata Megawati Setyawati Soekarnoputri (62). Bagi mereka yang mengenalnya dan mengikuti lika-liku perjalanan perempuan pertama yang pernah menjadi presiden Indonesia itu, sudah bisa menduga bahwa ia akan menolak tawaran itu. Alasannya, konsistensi dan konstitusi. Sampai kapanpun, apapun pandangannya, Megawati akan konsisten terhadap konstitusi partai. Perjalanan

Detail politiknya telah membuktikan itu. (Paragraf ke-4)

Pada menit-menit terakhir menjelang batas izin pelaksanaan kongres, 6 Desember 1993 pukul 00.00, Megawati tampil ke mimbar dan menyatakan: "sayalah ketua umum DPP PDI/de facto". Tak lama kemudian, sekitar 500 polisi beserta pasukan anti huru-hara memasuki ruangan sidang, membubarkan seluruh peserta dan Maksud mengambil alih seluruh kendali dilokasi asrama haji Sukolilo Surabaya. (Paragraf ke-9)

Sejumlah kalangan PDI-P juga menyambut positif karena secara hitungan politik tawaran itu bakal "menyelamatkan" wajah PDI-P yang saat itu ditinggal mitra-mitranya di koalisi besar (Partai Golkar, Partai Hanura, Partai Gerindra, Partai Persatuan Pembangunan). Jusuf Kalla

Jurnal Ilmu Komunikasi, Vol. 1, No.1, April 2011

ISSN: 2088-981X 
Tingkatan \& Elemen

Pengingkaran

Kata Ganti

\begin{tabular}{|c|c|}
\hline & \\
\hline (Stuktur Mikro) & Bila mengurut langkah perjalanan Megawati, dari seorang ibu rumah \\
\hline \multirow[t]{2}{*}{ Stilistik } & $\begin{array}{l}\text { tangga biasa yang "minim" pengalaman politik sampai menjadi } \\
\text { Presiden RI pada tahun } 2001 \text { seharusnya "rapor" politik Mega sudah }\end{array}$ \\
\hline & komplet sehingga apabila sekarang ia mencalonkan kembali menjadi \\
\hline \multirow[t]{2}{*}{ Leksikon } & $\begin{array}{l}\text { presiden, sementara partainya hanya menduduki peringkat ketiga di } \\
\text { bawah Partai Demokrat dan Partai Golkar dalam Pemilihan Umum } \\
\text { legislatif 2009, ambisi kekuasaankah yang mendorong ? (Paragraf ke- } \\
1 \text { dari sub Judul Kembali bertarung) }\end{array}$ \\
\hline & $\begin{array}{l}\text { Sejumlah kalangan PDI-P juga menyambut positif karena secara } \\
\text { hitungan politik tawaran itu bakal "menyelamatkan" wajah PDI-P yang } \\
\text { saat itu ditinggal mitra-mitranya di koalisi besar (Partai Golkar, Partai } \\
\text { Hanura, Partai Gerindra, Partai Persatuan Pembangunan). (Paragraf } \\
\text { ke-3) }\end{array}$ \\
\hline (Stuktur Mikro) & Tabel Kekayaan dan Utang: \\
\hline Retoris & $\begin{array}{l}\text { Panjang }=5 \mathrm{~cm} \text {, lebar }=8,8 \mathrm{~cm} \text {. Total kekayaan kandidat presiden } \\
\text { Megawati sebesar Rp. } 256.447 .223 .594 \text { (Font Bold) }\end{array}$ \\
\hline \multirow[t]{4}{*}{ Grafis } & Ukuran keseluruhan halaman Koran : Panjang $=57,4 \mathrm{~cm}$, lebar $=36$ \\
\hline & $\begin{array}{l}\text { cm. } \\
\text { Ukuran font tema utama = 1,5 cm. warna merah. }\end{array}$ \\
\hline & Ukuran space pemberitaan, iklan, dan gambar: \\
\hline & Berita: Panjang $=26,8 \mathrm{~cm}$, lebar $=32,3 \mathrm{~cm}, 20$ Paragraf \\
\hline
\end{tabular}

dan Wiranto sudah "lebih cepat" mencalonkan diri sebagai pasangan capres cawapres. Sementara Prabowo Subianto saat itu masih menjajaki kemungkinan peluangnya menjadi capres dengan merapat ke sejumlah partai. (Paragraf ke-3)

Bila mengurut langkah perjalanan Megawati, dari seorang ibu rumah tangga biasa yang "minim" pengalaman politik sampai menjadi Presiden RI pada tahun 2001 seharusnya "rapor" politik Mega sudah komplet sehingga apabila sekarang ia mencalonkan kembali menjadi presiden, sementara partainya hanya menduduki peringkat ketiga di bawah Partai Demokrat dan Partai Golkar dalam Pemilihan Umum legislatif 2009, ambisi kekuasaankah yang mendorong ? (Paragraf ke1 dari sub Judul Kembali bertarung)

(Stuktur Mikro) Kalimat Aktif :

Sintaksis Ia membangun partai tandingan, yaitu PDI Perjuangan dan menolak Bentuk Kalimat mengosongkan kantor PDI di jalan Diponegoro Jakarta. (Paragraf ke10)

Kalimat Pasif :

Megawati memang kemudian "berhasil" dilengserkan pemerintah melalui kongres PDI berikutnya. (Paragraf ke-10)

Kepada Kompas, Megawati mengatakan bahwa Kongres PDI-P telah memberi mandat kepada dirinya untuk mencalonkan diri sebagai presiden. Dan, itu adalah keputusan yang tidak bisa dikompromikan. (Paragraf ke-5)

Dan, seperti kita ketahui kemudian, meski melalui perundingan alot, Megawati akhirnya memang bersanding dengan Prabowo Subianto untuk bertarung dalam Pemilu Presiden 8 Juli 2009. (kata ganti "kita") (Paragraf ke-6) komplet sehingga apabila sekarang ia mencalonkan kembali menjadi presiden, sementara partainya hanya menduduki peringkat ketiga di legislatif 2009, ambisi kekuasaankah yang mendorong ? (Paragraf kebertarung)

Sejumlah kalangan PDI-P juga menyambut positif karena secara ke-3)

Berita: Panjang $=26,8 \mathrm{~cm}$, lebar $=32,3 \mathrm{~cm}, 20$ Paragraf

Jurnal Ilmu Komunikasi, Vol. 1, No.1, April 2011

ISSN: 2088-981X 
Iklan: panjang $=12 \mathrm{~cm}$, lebar $=32,3 \mathrm{~cm}$.

Gambar: Megawati tersenyum dengan menggunakan kerudung dan baju putih. Panjang $=23 \mathrm{~cm}$, lebar $17,8 \mathrm{~cm}$,

Jumlah lembar koran keseluruhan = 5 lembar, mulai halaman 33-42.

Jika ada rasa dendam secuil pun dalam sanubariku, itu akan meracuni

Metafora nuraniku, ujarnya suatu ketika. (Paragraf ke-5 dari sub judul kembali bertarung)

Judul ini menceritakan perjalanan Megawati ketika mendapatkan tawaran koalisi dengan Partai Demokrat melalui sinyal-sinyal yang dienduskan oleh Susilo Bambang Yudhoyono. Lebih lanjut, pembahasan pemberitaan ini mengarah kepada konsistensi Megawati dalam mencermati semua tawaran yang ada. Hingga sampai mengulas karakter dasar seorang Megawati dalam menjalankan roda kepartaian Partai Demokrasi Indonesia. Mulai proses perlawanan terhadap rezim orde baru yang menggambarkan sosok Megawati pantang menyerah, walaupun pemerintah waktu itu meng-intervensi keberlangsungan Partai Demokrasi Indonesia.

\section{Tabel 4}

b. Judul: Megawati Soekarnoputri: Bergerak pada Masa Transisi Bangsa

(Penulis: Umi Kulsum/Litbang Kompas)

Tingkatan \&

Strategi Penulisan

Elemen

\section{(Stuktur Makro) Judul: Bergerak pada Masa Transisi Bangsa.} Tematik

(Superstuktur) Bentuk tulisan piramida terbalik, inti berita ada di atas kemudian Skematik mengalir dengan kronologis cerita. Summary: Wanita yang lahir di Yogyakarta pada 23 Januari 1947 dengan nama Dyah Setyawati Soekarnoputri ini menghabiskan masa sekolah dasar hingga menengah atas di Yayasan Perguruan Cikini. Dia pernah kuliah di Universitas Padjajaran dan Universitas Indonesia, tetapi tekanan politik saat itu mengakibatkan dia tidak dapat menyelesaikan studinya. (Lead)

Story: Eksistensi Megawati sebagai simbol perlawanan Orde Baru Sub Judul: Grafis Kronologi Megawati (tabel ini mengungkap rekam jejak Megawati selama hidupnya, mulai lahir 23 Januari 2009 sampai 22 Juni 2009 saat kampanye menandatangani kontrak politik dengan perwakilan petani di Jawa Tengah)

Sub judul: Grafis Kiprah Megawati (tabel ini merangkum semua karier dan kiprah Megawati mulai dari awal masuk parlemen 17 Juni 1987 hingga putus hubungan dengan IMF saat Megawati menjadi Presiden). 
Tingkatan \& Elemen

(Stuktur Mikro) Semantik Latar

Detail

\section{Strategi Penulisan}

Semasa Orde Baru kerinduan akan sosok Soekarno seolah ditumpahkan pada Megawati. Maka, tak ayal Megawati menjadi sosok yang kuat di PDI, meruntuhkan kekuatan Soeryadi sebagai ketua umum PDI saat itu. Naiknya pamor Megawati bahkan di nilai berpotensi mengganggu stabilitas pemerintahan Orde Baru saat itu sehingga ketika Kongres Luar Biasa PDI di Surabaya memilih Megawati sebagai Ketua Umum Partai, intrik politik pun mulai bergentayangan. (Paragraf ke-2)

Pemilihan Umum 1999 menjadi Pemilihan Umum paling fenomenal sejak Masa Orde baru dimulai karena saat itu rezim lama telah tumbang dan PDI-Perjuangan telah memberikan sosok baru menjadi harapan rakyat Indonesia. Kejenuhan akan represi politik Orde Baru menjadikan PDI-Perjuangan menjadi pilihan pertama rakyat Indonesia hingga meraih suara. (Paragraf ke-5)

Peristiwa yang fenomenal adalah kerusuhan 27 Juli 1996 sebagai bentuk tirani kekuasaan saat itu yang mencoba mengusir massa pendukung Megawati dari kantor pusat PDI Jalan Diponegoro. Penyerangan kantor DPP PDI tersebut bukannya menyurutkan semangat para banteng muda, tetapi justru makin mengukuhkan eksistensi Megawati sebagai simbol perlawanan Orde baru. (Paragraf ke-3)

(Stuktur Mikro) Kalimat Pasif

Sintaksis Semasa Orde Baru kerinduan akan sosok Soekarno seolah

Bentuk Kalimat ditumpahkan pada Megawati. (Paragraf ke-2)

Semasa Orde Baru kerinduan akan sosok Soekarno seolah Koherensi ditumpahkan pada Megawati. Maka, tak ayal Megawati menjadi sosok yang kuat di PDI, meruntuhkan kekuatan Soeryadi sebagai ketua umum PDI saat itu. (Paragraf ke-2)

(Stuktur Mikro) ….., menguras simpanan pemerintah dan menjual aset Badan Stilistik Penyehatan Perbankkan Nasional. (Paragraf ke-7)

Leksikon

(Stuktur Mikro)

Grafis berwarna merah.

Grafis Kiprah Megawati:

Panjang $=6,2 \mathrm{~cm}$, lebar $=21,5 \mathrm{~cm}$, dengan design layout mencolok berwarna merah.

Ukuran keseluruhan halaman Koran : Panjang $=57,4 \mathrm{~cm}$, lebar $=36$

$\mathrm{cm}$.

Ukuran font tema utama $=1,5 \mathrm{~cm}$, warna merah dan hitam.

Ukuran space pemberitaan, iklan, dan gambar:

Berita: panjang $=29,5 \mathrm{~cm}$, lebar $=10,5 \mathrm{~cm}, 8$ Paragraf

Iklan 1: panjang $=15 \mathrm{~cm}$, lebar $=9 \mathrm{~cm}$.

Iklan 2: panjang $=15 \mathrm{~cm}$, lebar $=23 \mathrm{~cm}$.

Gambar: Megawati dengan mengacungkan jari telunjuk, tidak mengenakan kerudung dan berbaju putih. Panjang $=24,5 \mathrm{~cm}$, lebar $25,5 \mathrm{~cm}$.

Jurnal Ilmu Komunikasi, Vol. 1, No.1, April 2011 
Berita ini menceritakan tentang bagaimana seorang Megawati yang dilahirkan di sebuah keluarga penguasa, yaitu putri presiden Soekarno. Megawati mulai menunjukkan kiprahnya ketika terjun sebagai ketua PDI Cabang Jakarta Pusat pada tahun 1987. Menggambarkan sosok Soekarno seolah-olah terobati dengan adanya Megawati, sampai Megawati menjadi sosok yang kuat di tubuh PDI dengan mengalahkan kekuatan Soerjadi sebagai Ketua Umum PDI.

Tabel 5

Judul: Putri Proklamator yang Berjuang dengan Kekerasan Hati

(Penulis: Bagus Takwin, Niniek L Karim, Diki Pelupessy, dan Nurlyta Hafiyah)

Tingkatan \&

Strategi Penulisan

Elemen

(Stuktur Makro) Judul: Putri Proklamator yang Berjuang dengan Kekerasan Hati.

Tematik

(Superstuktur) Bentuk tulisan balok tegak, inti berita menyebar, tidak hanya pada Skematik satu titik saja.

Summary: Pertahanan terbaik adalah "menyerang", ungkapan ini bisa menggambarkan strategi Megawati Soekarnoputri. Sejalan dengan pilihan partainya, ia menjalankan peran oposisi secara maksimal. Dengan menggunakan strategi mengingatkan jasa dan arti usaha sang proklamator yang mencetuskan UUD 1945 dan Pancasila, belakangan ini Megawati aktif mengkritik pemerintahan yang dipimpin SBY. (Lead) Story: menggambarkan sosok Megawati suka mengkritik pemerintah. Sub judul: Prinsip Moral

Penampilan Megawati syarat kritik, menekankan pentingnya harga diri serta prinsip moral yang diyakini sejalan dengan cirri-ciri kepribadian anak kedua atau anak tengah yang diuraikan Alfred Adler (1870-1973). (Paragraf ke-1 dari sub judul Prinsip Moral)

Sub judul: Aspek Kognitif: trait (sifat), belief (kepercayaan), kompleksitas pikiran dan pola penalaran.

Megawati suka tantangan, sifat yang juga menonjol pada kepribadian anak kedua. Ia cenderung menghindari area yang sudah dijalani kebanyakan orang, mencari jalan yang tidak umum untuk menemukan keleluasaan mencapai kesempurnaan, dan menunjukkan kepada dunia bahwa ia layak diperhatikan, layak menjadi nomer satu. Kekerasan hati anak kedua membawanya kepada prestasi "puncak" menjadi presiden RI, menggantikan Abdurrahman Wahid. (Paragraf ke-1 dari sub judul Aspek Kognitif: trait (sifat), belief (kepercayaan), kompleksitas pikiran dan pola penalaran)

Sub judul: Motif Sosial

Belakangan Megawati tampak banyak menampilkan indikasi kebutuhan kekuasaan. Dorongan menjadi pemimpin dan memengaruhi banyak orang semakin jelas terlihat, terutama saat ia berpidato. Masyarakat pun menangkap kesan bahwa Megawati sangat berambisi untuk berkuasa kembali dibanding dua kandidat lain. (Paragraf ke-1 dari sub judul Motif sosial)

Sub judul: Kepribadian dan Kepemimpinan Megawati

Ada beberapa kecenderungan yang umumnya dianggap berlawanan, secara bersamaan ada pada Megawati. Ia bisa mengesankan dirinya

Jurnal Ilmu Komunikasi, Vol. 1, No.1, April 2011

ISSN: 2088-981X 
Tingkatan \& Elemen

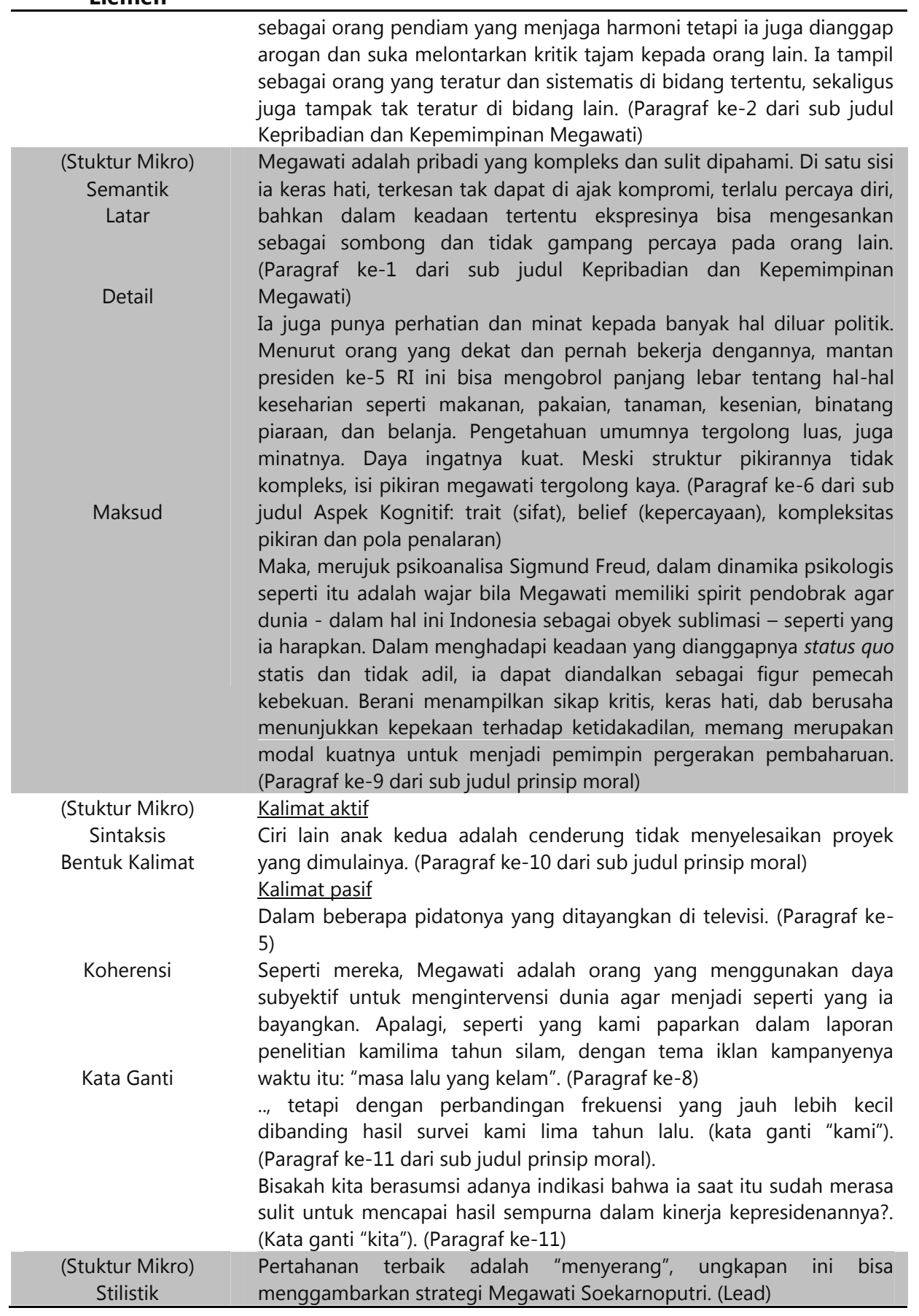

Jurnal Ilmu Komunikasi, Vol. 1, No.1, April 2011

ISSN: 2088-981X 


\section{Tingkatan \&}

Strategi Penulisan

Elemen

Leksikon

(Stuktur Mikro)

Retoris

Grafis

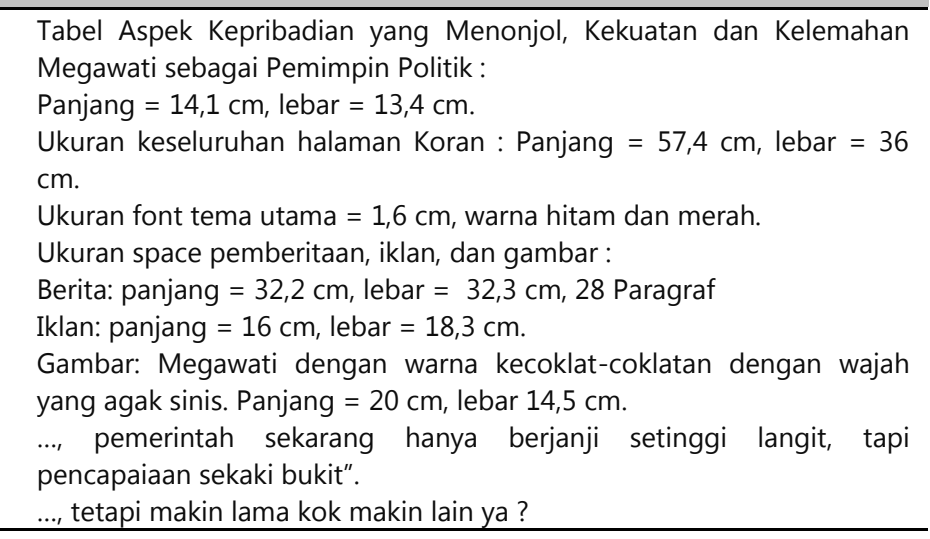
..., tetapi makin lama kok makin lain ya ?

Metafora

Pemberitaan ini menggambarkan Megawati dengan kepribadiannya, yang paling ditonjolkan adalah kepribadian menyerang dan suka melontarkan kritik tajam kepada orang lain. Isi dari berita ini juga mengacu pada Psikoanalisis Sigmund Freud, dijelaskan di dalamnya sosok Megawati seperti sosok tokoh pendobrak dunia, antara lain: Mahatma Gandhi, Marthin King Luther, semua merupakan anak kelahiran di tengah atau anak tengah.

\section{Konstruksi Wacana Harian Kompas Edisi 30 Juni 2009 (Kandidat Presiden Susilo Bambang Yudhoyono)}

Tabel 6

a. Judul: Susilo Bambang Yudhoyono: Demokrasi

dan Mimpi Anak Bangsa (Penulis: Wisnu Nugroho)

Tingkatan \&

Strategi Penulisan

\section{Elemen}

(Stuktur Makro) Judul: Susilo Bambang Yudhoyono: Demokrasi dan Mimpi Anak Desa

Tematik (Font Susilo Bambang Yudhoyono capital berwarna merah, font Demokrasi menggunakan capital berwarna biru menyala sesuai dengan warna Partai Demokrat, sedangkan font dan mimpi anak bangsa menggunakan Capitalize Each Word berwarna hitam)

(Superstuktur) Bentuk berita menggunakan balok tegak, inti gagasan menyebar Skematik dimana-mana.

Summary: Diantara tiga calon presiden yang maju bertarung dalam Pemilu Presiden 2009, Susilo Bambang Yudhoyono adalah contoh kegigihan anak desa tanpa modal nama besar keluarga meraih mimpinya. Muhammad Jusuf Kalla menyandang nama besar ayahnya, Hadji Kalla, saudagar sukses. Megawati Soekarnoputri menyandang nama besar ayahnya, Soekarno, Presiden RI pertama. (Lead)

Nasib baik selalu menyertai Yudhoyono, setidaknya sampai Pemilu Presiden 2004 putaran kedua. Berangkat meninggalkan Desa Tremas,

Jurnal Ilmu Komunikasi, Vol. 1, No.1, April 2011

ISSN: 2088-981X 
$\mathbf{5 0}$ | Sholihul Huda dan Ali Nurdin

Tingkatan \&

Strategi Penulisan

Elemen

Pacitan, Jawa Timur, setelah kedua orangtuanya bercerai, Yudhoyono menapaki jalan hidupnya dan menyusun mimpinya. (sub lead)

Story: Perjalanan Yudhoyono semasa hidup

Sub judul: Berawal dari Magelang

Dari Magelang yang sejuk dan tenang, jalan hidup Yudhoyono ditata. Dengan latar belakang keluarga yang biasa-biasa saja, Yudhoyono justru memiliki motifasi ganda diantara temannya yang punya "nama keluarga". Yudhoyono masuk Akabri satu angkatan dengan Prabowo Subianto, Agus Wirahadikusumah, Ryamizard Ryacudu, dan Yudi M Yusuf. (Paragraf ke-1 dari sub judul berawal dari Magetan)

Sub judul: Kembali ke Bandung

Diawali dengan lencana Adhi Makayasa dan Kristiani Herawati di dada, Yudhoyono mendapati kecemerlangan karier militernya tapak demi tapak. Bandung, Jawa Barat, menjadi kota yang paling lama disinggahi dalam karier militernya. Lebih dari separuh karier militer Yudhoyono sepanjang 25 tahun ditapaki di Bandung. (Paragraf ke-1 dari sub judul kembali ke Bandung)

Demokrasi telah terbukti mampu menjadi jembatan dari mimpi seorang anak desa yang kini sudah tinggal di kota dan hidup berkecukupan. (sub lead)

Sub judul:Yudhoyono ke SBY

Lepas dari karier militer, Yudhoyono mulai menapaki karier politiknya. Dibawah pemerintahan Abdurrahman Wahid dan Megawati Soekarnoputri, Yudhoyono melihat peluang menjadi wakil presiden dan presiden. Untuk karier politik itu, anak desa yang sudah tinggal di Puri Cikeas Indah, Bogor, Jawa Barat, itu mengubah nama panggilan menjadi SBY. (Paragraf ke-1 dari sub judul Yudhoyono ke SBY)

Sub judul: SBY jilid dua

Setelah dilantik dan diambil sumpahnya sebagai presiden, SBY tinggal di Istana Kepresidenan, Jakarta. Didampingi istri, dua putra, ibu, dan ibu mertuanya, SBY mencapai puncak kerier di Istana Merdeka. Doa pagi hari semua anggota keluarga mengawali pergerakannya dari Cikeas ke Istana. (Paragraf ke-1 dari sub judul SBY jilid dua)

Tabel Kekayaan dan Utang (berisi harta kekayaan yang dimiliki SBY dan juga hutangnya, sehingga dalam tabel tersebut merinci total harta kekayaan dan hutan SBY)

Jurnal Ilmu Komunikasi, Vol. 1, No.1, April 2011

ISSN: 2088-981X 
Tingkatan \&

Elemen

\begin{tabular}{|c|c|}
\hline (Stuktur Mikro) & Nyaris sendiri, anak tunggal ini menyongsong mimpinya keluar dari \\
\hline $\begin{array}{l}\text { Semantik } \\
\text { Latar }\end{array}$ & $\begin{array}{l}\text { Pacitan yang gersang dan terpencil. Seperti ayahnya, Soekotjo, seorang } \\
\text { tentara, Yudhoyono bercita-cita menjadi tentara. Kerena terlambat } \\
\text { mendaftar, Yudhoyono "terasing" nyaris dua tahun sebelum masuk }\end{array}$ \\
\hline & Akademi Angkatan Bersenjata Republik Indonesia (Akabri). (Paragraf \\
\hline Detail & $\mathrm{ke}-1)$ \\
\hline Maksud & $\begin{array}{l}\text { Pada akhir tahun pendidikannya di Akabri, Yudhoyono yang dijuluki } \\
\text { Jerapah karena postur tubuhnya, mendapat dua anugerah. Pertama, } \\
\text { predikat lulusan terbaik Akabri } 1973 \text { dengan mandapat lencana Adhi } \\
\text { Makayasa. Presiden Soeharto yang menyematkan lencana itu di dada } \\
\text { Yudhoyono. Kedua, Kristiani Herawati yang tersemat erat di dadanya } \\
\text { sampai kini. (Paragraf ke-2 dari sub judul Berawal dari Malang) }\end{array}$ \\
\hline Pra-anggapan & $\begin{array}{l}\text { Diakui atau tidak, jalan hidup dan karier SBY menginspirasi banyak } \\
\text { orang. Dari desa Tremas, Pacitan, yang tandus penuh bebatuan, SBY } \\
\text { bisa meraih mimpi tertingginya di Indonesia. Dari keluarga biasa saja } \\
\text { dan bercerai pula, SBY bisa menjadi inspirasi keluarga-keluarga di } \\
\text { Indonesia. (Paragraf ke-4 dari subjudul SBY jilid dua) } \\
\text { Jika mimpi itu terwujud sekali lagi, SBY yang lebih pasti menjamin } \\
\text { peralihan generasi kepemimpinan di Indonesia pada tahun 2014. Jika } \\
\text { terpilih, karena konstitusi, SBY tidak lagi akan mempertahankan } \\
\text { kekuasaannya. Peluang kepemimpinan ke depan terbuka untuk } \\
\text { generasi muda dari desa mana saja. (Paragraf ke-6 dari sub judul SBY } \\
\text { jilid dua). }\end{array}$ \\
\hline (Stuktur Mikro) & $\underline{\text { Kalimat pasif }}$ \\
\hline Sintaksis & Keluarga baru didapatkan Yudhoyono setelah keluarganya terpecah \\
\hline Bentuk kalimat & $\begin{array}{l}\text { karena perceraian orang tuanya semasa remaja. (Paragraf ke- } 8 \text { dari sub } \\
\text { judul Berawal dari Malang) }\end{array}$ \\
\hline Koherensi & $\begin{array}{l}\text { Nyaris sendiri, anak tunggal ini menyongsong mimpinya keluar dari } \\
\text { Pacitan yang gersang dan terpencil. (Paragraf ke-1) }\end{array}$ \\
\hline $\begin{array}{l}\text { (Stuktur Mikro) } \\
\text { Stilistik }\end{array}$ & $\begin{array}{l}\text { Hubungan Yudhoyono dengan Kristiani tak terkendala karena "lampu } \\
\text { hijau" juga telah diberikan Ny Sarwo Edhie, penentu utama. (Paragraf }\end{array}$ \\
\hline Leksikon & ke-5 dari sub judul Berawal dari Malang). \\
\hline & $\begin{array}{l}\text { Karena terlambat mendaftar, Yudhoyono "terasing" nyaris dua tahun } \\
\text { sebelum masuk Akademi Angkatan Bersenjata Republik Indonesia } \\
\text { (Akabri). (Paragraf ke-1) }\end{array}$ \\
\hline (Stuktur Mikro) & Tabel Kekayaan dan Utang : \\
\hline Retoris & Panjang $=6 \mathrm{~cm}$, lebar $=10,5 \mathrm{~cm}$. Total kekayaan kandidat presiden \\
\hline Grafis & $\begin{array}{l}\text { Susilo Bambang Yudhoyono sebesar Rp. } 6.848 .049 .611 \text { dan } 246.389 \\
\text { Dollar AS. (Font Bold) }\end{array}$ \\
\hline & $\begin{array}{l}\text { Ukuran keseluruhan halaman Koran : Panjang }=57,4 \mathrm{~cm} \text {, lebar }=36 \\
\mathrm{~cm} \text {. }\end{array}$ \\
\hline & Ukuran font tema utama = $2 \mathrm{~cm}$. warna merah, biru, dan hitam. \\
\hline & Ukuran space berita, dan gambar: \\
\hline
\end{tabular}

Jurnal Ilmu Komunikasi, Vol. 1, No.1, April 2011

ISSN: 2088-981X 
Tingkatan \&

Berita: Panjang $=34,5 \mathrm{~cm}$, lebar $=32,3 \mathrm{~cm}, 33$ Paragraf

Gambar: SBY tersenyum dengan mengangkat tangan kanannya, berbaju biru sesuai dengan warga Partai Demokrat. Panjang $=31 \mathrm{~cm}$, lebar $17 \mathrm{~cm}$.

Jumlah lembar koran keseluruhan = 4 lembar, mulai halaman 33-40. "Ini sudah menjadi tekad saat berdoa di pernikahan Yudhoyono-

Ekspresi Kristiani di Cijantung," ujar Djoko. (Paragraf ke-2 dari sub judul SBY jilid dua)

Berita ini mulai dari lead sudah sangat kelihatan penonjolan akan kebaikan kandidat presiden Susilo Bambang Yudhoyono. Wartawan menggambarkan sosok SBY yang dianggapnya mempunyai nasib baik, sehingga dalam tulisannya ini wartawan mengajak pembaca untuk mengikuti ritme tulisan yang dibuatnya (lihat tabel pada lead). Dari paragraf pertama sampai ketiga penulisan ini sistematis dan runtut dalam menggambarkan sifat baik SBY. Sisi kelebihan lainnya begitu kuat digambarkan sehingga ketika menyangkut masalah kelemahan wartawan enggan untuk terlalu meng-eksposenya.

Tabel 7

b. Judul: Susilo Bambang Yudhoyono: Jenderal "Akademis" di Panggung Politik (Penulis: MG Retno Setyowati/Litbang Kompas)

Tingkatan \& Strategi Penulisan Elemen

(Stuktur Makro) Susilo Bambang Yudhoyono: Jenderal "Akademis" di Panggung Politik Tematik

(Superstuktur) Yudhoyono kembali maju untuk pemilihan presiden mendatang. Kali Skematik ini ia tidak lagi bersama Jusuf Kalla sebagai wakilnya, tetapi lebih memilih Boediono. Jadi, pemilihan umum presiden mendatang merupakan arena persaingan untuk kedua kalinya. (Lead)

Susilo Bambang Yudhoyono lahir pada 9 September 1949 di Tremas, Arjosari, Pacitan, Jawa Timur, sebagai anak tunggal pasangan Raden Soekotjo (pensiunan letnan satu) dan Siti Habibah, anak salah satu pendiri ponpes Tremas. Nama Susilo Bambang Yudhoyono bermakna santun, penuh kesusilaan (susilo), ksatria (bambang), perang (yudho), kemenangan (yono). (Sub lead)

Grafis Karier Militer (menggambarkan tentang kiprah SBY selama di militer, mulai dari masuk Akabri pada usia 24 tahun sampai mendapat kenaikan pangkat kehormatan dari Letnan Jenderal menjadi jenderal pada usia ke-51 tahun).

Grafis Jejak SBY

(merekam jejak perjalanan hidup SBY, mulai dari lahir 9 September 1949 sampai pada 12 Mei 2009 memilih gubernur BI Boediono menjadi calon wakil presiden, ia memutuskan tidak lagi bersama Jusuf Kalla)

Jurnal Ilmu Komunikasi, Vol. 1, No.1, April 2011

ISSN: 2088-981X 
Tingkatan \& Elemen

(Stuktur Mikro)

Semantik

Latar

Detail

\section{Strategi Penulisan}

Karier politiknya diawali pada 29 Oktober 1999 ketika diangkat menjadi Menteri Pertambangan dan Energi masa pemerintahan Presiden KH Abdurrahman Wahid. Saat itu dia berpangkat letnan jenderal dan memutuskan pensiun dini dengan pangkat jenderal kehormatan. Setahun kemudian, Presiden Wahid mengangkatnya sebagai Menteri Kordinator Bidang Politik dan Keamanan. Namun, jabatan itu hanya dijalankan selama setahun, ia lalu mundur dari kabinet. (Paragraf ke-5)

Selama 27 tahun meniti karier di TNI AD, SBY banyak memimpin satuan tugas tempur. Lalu kemudian, ia menjadi Kassospol pada 1998. Saat itulah, peran sosial maupun politik TNI secara perlahan ditiadakan. Jabatan ini pun berubah menjadi kepala staf territorial dan SBY sebagai yang pertama memegang jabatan itu. SBY berperan banyak dalam upaya mereposisi peran TNI (ABRI). (Paragraf ke-4) Setalah lulus SMA akhir 1968, Susilo yang kini lebih dikenal dengan sebutan SBY berebcana melanjutkan ke Akademi Angkatan Bersenjata Republik Indonesia (Akabri). Namun, karena terlambat mendaftar, SBY tidak langsung masuk Akabri. Ia sempat menjadi mahasiswa Teknik Mesin Institut 10 Nopember Surabaya - hanya mengikuti tahapan orientasi kampus. Dia lebih memilih masuk pendidikan guru sekolah lanjutan pertama di Malang. (Paragraf ke-2)

(Stuktur Mikro) Ia kemudian dicalonkan untuk memperebutkan jabatan wakil presiden Sintaksis yang kosong setelah Megawati Soekarnoputri menjadi Presiden. Bentuk kalimat (Paragraf ke-6)

Koherensi Dua bulan kemudian, Megawati menunjuknya sebagai Menteri Koordinator Bidang Politik dan Keamanan. Namun, kemelut politik yang terjadi yang menghadapkan dirinya dengan Megawati, SBY memilih mundur dari jabatannya sebagai Menko Polkam pada 11 Maret 2004. (Paragraf ke-6)

\begin{tabular}{|c|c|}
\hline $\begin{array}{c}\text { (Stuktur Mikro) } \\
\text { Stilistik } \\
\text { Leksikon }\end{array}$ & Jenderal "akademis" di panggung politik. (Judul) \\
\hline $\begin{array}{c}\text { (Stuktur Mikro) } \\
\text { Retoris } \\
\text { Grafis }\end{array}$ & $\begin{array}{l}\text { Grafis Karir Militer Susilo Bambang Yudhoyono: } \\
\text { Panjang }=12,7 \mathrm{~cm} \text {, lebar }=21,5 \mathrm{~cm} \text {. } \\
\text { Grafis Jejak Susilo Bambang Yudhoyono: } \\
\text { Panjang }=13,3 \mathrm{~cm} \text {, lebar }=27 \mathrm{~cm} \text {. } \\
\text { Ukuran keseluruhan halaman Koran : Panjang }=57,4 \mathrm{~cm} \text {, lebar = } 36 \\
\mathrm{~cm} \text {. } \\
\text { Ukuran font tema utama }=1,2 \mathrm{~cm} \text {, warna merah dan biru. } \\
\text { Ukuran space pemberitaan, dan gambar: } \\
\text { Berita: panjang }=11,5 \mathrm{~cm} \text {, lebar }=5 \mathrm{~cm}, 9 \text { Paragraf } \\
\text { Gambar: SBY tersenyum dengan mengacungkan jari telunjuk } \\
\text { kanannya ke atas. Memakai baju warna putih. Panjang }=34,5 \mathrm{~cm} \text {, } \\
\text { lebar } 28,5 \mathrm{~cm}\end{array}$ \\
\hline
\end{tabular}

Berita ini masih mendalami dan meneruskan seputar perjalanan SBY mulai lahir hingga berkarya, seperti berita pertama. Menceritakan kisah SBY dimasa 
kecil yang digambarkan sebagai orang yang pintar, aktif dsb. Berita ini tidak begitu banyak, dan lebih kepada pemahaman ke arah profil SBY semasa hidupnya. Menegaskan ulang seperti yang sudah tercantum di berita pertama, terkait kronologis pendidikan SBY hingga masuk diterima di AKABRI, tentunya dari perjalanan yang panjang. Dan juga dijelaskan beberapa prestasi yang diperoleh oleh SBY selama masa pendidikan di AKABRI tersebut.

Tabel 8

c. Judul: Susilo Bambang Yudhoyono: Berjuang Menjadi Pahlawan

(Penulis: Bagus Takwin, Niniek L Karim, Nurlyta Hafiyah, dan Dicky Pelupessy)

Tingkatan \&

Strategi Penulisan

Elemen

(Stuktur Makro) Susilo Bambang Yudhoyono: Berjuang Menjadi Pahlawan

Tematik

(Superstuktur)

Summary: Susilo Bambang Yudhoyono atau SBY, anak tunggal yang

Skematik

charming itu, telah menjadi Presiden RI selama hamper 5 tahun dan mencalonkan diri lagi untuk periode tahun 2009-2014. (Lead)

SBY terbuka pada ide baru, sejauh itu tak bertentangan dengan norma masyarakat. (sub lead)

Story: Kisah SBY sejak kecil

Sub judul: aspek kognitif: "Trait" (sifat), "Belief" (kepercayaan), Kompleksitas Pikiran - Pola Penalaran.

SBY tetap menampilkan diri sebagai orang yang menaati norma sosial. Ia menghargai tradisi masyarakatnya, menghormati atasan dan orang yang lebih tua, mengutamakan sopan santun, menjunjung tinggi kehormatan, menilai tinggi moralitas, disiplin ketat, dan memanfaatkan waktu secara efisien. Pada awal hidup, seorang anak tunggal cenderung manjadikan sifat-sifat itu sebagai alat untuk memperoleh perhatian simpati sosial, dalam perkembangannya sangat mungkin sifat-sifat itu terinternalisasi menjadi bagian dari kepribadiannya. (Paragraf ke-1 dari sub judul : aspek kognitif: "Trait" (sifat), "Belief" (kepercayaan), Kompleksitas Pikiran - Pola Penalaran). Sub judul: Motif sosial

Indikasi kebutuhan kekuasaan juga dapat dikaitkan dengan perjuangannya untuk menjadi pahlawan: menghasilkan perubahan yang member pengaruh positif kepada banyak orang. (Paragraf ke-4 dari sub judul Motif sosial)

Sub judul: Kepribadian dan kepemimpinan SBY

Selama menjadi Presiden RI, perilaku SBY tampak masih dibayangi sifat dasarnya. Ia masih membutuhkan dasar formal yang kuat bagi tindakan politiknya, berkonsultasi dengan banyak pihak sebelum mengambil keputusan, dan berusaha tampil popular. Dalam situasi yang mengambang dan tak jelas, ia masih belum berani mengambil keputusan yang tegas, "jalan tengah" menjadi alternative terbaik baginya. Kebijakan dan keputusan yang merupakan terobosan baru belum cukup banyak dihasilkan oleh SBY. (Paragraf ke-1 dari sub judul Kepribadian dan kepemimpinan SBY)

Jurnal Ilmu Komunikasi, Vol. 1, No.1, April 2011

ISSN: 2088-981X 
Tingkatan \& Elemen

(Stuktur Mikro) Semantik Latar

Detail

Pra-anggapan

Pengingkaran

Stuktur Mikro)

Sintaksis

Bentuk Kalimat

Koherensi

Kata ganti

(Stuktur Mikro)

Stilistik

Leksikon

\section{Strategi Penulisan}

Dalam sebuah artikel tentang pahlawan yang ditulisnya di majalah Time Asia (10 Oktober 2005), SBY bertanya kepada dirinya, jika dihadapkan dalam situasi yang dijalani para pahlawan, apakah ia akan menampilkan tindakan yang sama. Jawabannya, " Mungkin memang terdapat sosok seorang pahlawan dalam diri kita masing-masing. Kita hanyalah perlu untuk mengejawantahkannya. " Apakah SBY sedang berusaha mengejawantahkan potensinya untuk menjadi pahlawan?. (Paragraf ke-10)

Meski indikasi dari keinginan untuk menjadi pahlawan pada diri SBY, seperti gencarnya pemberantasan korupsi atas perintahnya, adalah indikasi dari pengejawantahan sifat pahlawan. Namun aktualita ini terkesan masih belum optimal. Sikap kepahlawanan masih banyak yang diharapkan SBY. Dalam arti masyarakat masih sangat mengharapkan tindakan nyata SBY. (Paragraf ke-19)

Untuk menjadi pahlawan, seseorang harus berani mengambil resiko dan terus menerus berusaha meningkatkan usahanya tersebut. Kesan yang kadang masih tertangkap dari SBY adalah kurang berani mengambil resiko. Walau demikian, indikasi dari keberanian mengambil resiko dan menghadapi konflik tampak sudah mulai tampil pada diri SBY. Artinya, ia sedang berjuang untuk menjadi pahlawan yang dapat diandalkan banyak orang. (Paragraf ke-18)

Walau demikian, indikasi dari keberanian mengambil resiko dan menghadapi konflik tampak sudah mulai tampil pada diri SBY. Artinya, ia sedang berjuang untuk menjadi pahlawan yang dapat diandalkan banyak orang. (Paragraf ke-18)

Kesan yang kadang masih tertangkap dari SBY adalah kurang berani mengambil resiko. Walau demikian, indikasi dari keberanian mengambil resiko dan menghadapi konflik tampak sudah mulai tampil pada diri SBY. Artinya, ia sedang berjuang untuk menjadi pahlawan yang dapat diandalkan banyak orang. (Paragraf ke-18)

\section{Kalimat aktif}

Di beberapa acara televisi, SBY menangkis tanggapan orang tentang dirinya, mempertahankan sepak terjangnya sebagai presiden. (Paragraf ke-2)

Kalimat pasif

Kebijakan dan keputusan yang merupakan terobosan baru belum cukup banyak dihasilkan oleh SBY.

Semula ia tampak selalu berusaha mempertahankan citra diri sebagai orang yang baik, taat pada norma sosial, dan berusaha tidak menyakiti orang lain dalam menjalankan peran sosial. (Paragraf ke-7)

Seperti dijabarkan dalam laporan penelitian kami pada tahun $2004, \ldots$. (kata ganti "kami"). (Paragraf ke-4)

Susilo Bambang Yudhoyono atau SBY, anak tunggal yang charming itu, telah menjadi Presiden RI selama hampir 5 tahun dan mencalonkan diri lagi untuk periode tahun 2009-2014. (Lead) ...,rasa kehilangan dan telantar akan yang menyakitkan, menimbulkan

Jurnal Ilmu Komunikasi, Vol. 1, No.1, April 2011

ISSN: 2088-981X 
Tingkatan \&

\section{Strategi Penulisan}

Elemen

\begin{tabular}{|c|c|}
\hline & $\begin{array}{l}\text { rasa cemas "sakit" itu akan terulang lagi. Kecemasan dalam usaha } \\
\text { melepas "topeng" ini dapat di atasi dengan kemampuan bekerja sama, } \\
\text { sifat realistik, dan menggalang solidaritas. (Paragraf ke-12) }\end{array}$ \\
\hline & $\begin{array}{l}\text { Semua kemampuan itu menjadi modal kuat SBY untuk menampilkan } \\
\text { "pedang kepemimpinannya", guna memotong putus segala yang } \\
\text { mengancam integritas sosial dan keberlangsungan hidup negara } \\
\text { Indonesia, sekaligus menemukan diri sendiri yang mandiri dan otentik. } \\
\text { (Paragraf ke-13) } \\
\text { Ia harus berani "mengambil" kembali kekuasaan dan kebebasan } \\
\text { pribadinya dari kelompok dan system sosial agar bisa member } \\
\text { sumbangan yang lebih bermakna bagi dirinya sendiri maupun bagi } \\
\text { keseluruhan bangsa. (Paragraf ke-2 dari sub judul Kepribadian dan } \\
\text { kepemimpinan SBY) }\end{array}$ \\
\hline $\begin{array}{l}\text { (Stuktur Mikro) } \\
\text { Retoris } \\
\text { Grafis }\end{array}$ & $\begin{array}{l}\text { Tabel Aspek Kepribadian yang Menonjol, Kekuatan dan Kelemahan } \\
\text { Susilo Bambang Yudhoyono sebagai Pemimpin Politik: } \\
\text { Panjang }=18,5 \mathrm{~cm} \text {, lebar }=1,5 \mathrm{~cm} \text {. } \\
\text { Ukuran keseluruhan halaman Koran : Panjang }=57,4 \mathrm{~cm} \text {, lebar }=36 \\
\mathrm{~cm} \text {. } \\
\text { Ukuran font tema utama }=2 \mathrm{~cm} \text {, warna merah, hitam, dan biru. } \\
\text { Ukuran space pemberitaan, dan gambar: } \\
\text { Berita: panjang }=45,3 \mathrm{~cm} \text {, lebar }=32,3 \mathrm{~cm} \text {, } 33 \text { Paragraf } \\
\text { Gambar: SBY dengan warna kecoklatan dengan mimik wajah serius } \\
\text { dan sedikit tersenyum. Panjang }=24,5 \mathrm{~cm} \text {, lebar } 15 \mathrm{~cm} \text {. }\end{array}$ \\
\hline Metafora & $\begin{array}{l}\text {...," } \text { Mungkin memang terdapat sosok seorang pahlawan dalam diri } \\
\text { kita masing-masing. Kita hanyalah perlu untuk } \\
\text { mengejawantahkannya." (Paragraf ke-10) }\end{array}$ \\
\hline
\end{tabular}

Berangkat dari leadnya sudah kelihatan dijelaskan kebaikan dari sifat SBY, dengan mengatakan "charming". Penonjolan sifat baik juga terlihat di hampir semua paragraf. Pada latar, dijelaskan bahwa SBY sebagai pemimpin yang akan berjuang menjadi pahlawan, dan penampilan majalah Time di dalam pemberitaan juga bisa menambah kekuatan SBY dimata masyarakat. Pada maksud, dijelaskan sifat SBY yang kurang tegas, tetapi dalam tulisan itu oleh wartawan seolah-olah ditutup-tutupi dan terkesan tidak begitu kelihatan karakter kurang tegas yang dimiliki oleh SBY tersebut. Bahkan, wartawan memberikan pemahaman yang baru, bahwa sikap tegas SBY sudah mulai tampak, dan ditegaskan kembali bahwa SBY sedang berjuang menjadi seorang pahlawan. 


\section{Konstruksi Wacana Harian Kompas Edisi 1 Juli 2009 (Kandidat Presiden Muhammad Jusuf Kalla)}

Tabel 9

a. Judul: Muhammad Jusuf Kalla: Sudah Kaya, Cari Apa Lagi?

(Penulis: Suhartono)

Tingkatan \&

Strategi Penulisan

Elemen

(Stuktur Makro) Judul: Muhammad Jusuf Kalla: Sudah Kaya, Cari Apa Lagi ?

Tematik

(Font Muhammad Jusuf Kalla, capital dan berwarna kuning sesuai dengan warna partai pengusungnya yaitu Golkar, sedangkan font Sudah Kaya Cari Apa Lagi, Capitalize Each Word dan menggunakan warna hitam)

(Superstuktur) Bentuk tulisan adalah balok tegak, inti gagasan menyebar.

Skematik Summary: Setelah resmi menjadi calon presiden, Muhammad Jusuf Kalla mengaku sering ditanya orang di sejumlah tempat. (Lead)

"Pak JK, Anda ini sudah kaya, tetapi Anda masih ingin menjadi presiden. Apa ingin lebih kaya lagi ?. Lalu, apa yang dicari ?" itulah cerita yang diungkapkan Kalla saat berkampanye dialogis di Pekanbaru, Riau, pertengahan Juni. (Sub lead)

Story: Perjalanan JK sebagai saudagar sukses

Sub judul: Bisnis keluarga

Kebijakan itu bisa dijalankan, tetapi harus ada langkah pemerintah untuk melakukan trobosan, seperti mengubah ketentuan. Itu namanya pemerintah. (Sub lead)

Sub judul: Rebut kesempatan

"Kalau kesempatan pembangunan itu tidak diambil. Kesempatan itu hilang diambil negara lain". Ujar Kalla dalam beberapa kali kampanye dialogis sebagai calon presiden di sejumlah tempat.

Tabel Kekayaan dan Hutang

(memberikan gambaran tentang harta kekayaan kandidat Jusuf Kalla serta hutang-hutangnya, digambarkan secara jelas sampai total keseluruhan)

(Stuktur Mikro) Kalla kemudian menjawab sendiri, "Tidak. Saya sudah cukup mampu Semantik untuk tidak mengambil apapun kekayaan dari negeri ini. Bersama pak Latar Wiranto (calon wakil presiden dari Partai Hanura), saya tidak mencari keuntungan apa-apa. Saya hanya mau bekerja, mencari kemuliaan dan kehormatan rakyat. Bukan kemuliaan dan kehormatan saya. Saya tidak mau meninggalkan bangsa yang kurang kehormatannya karena

Detail kurang mandiri dibidang ekonomi." (Paragraf ke-1)

Dalam catatan Kompas, dari berdagang Mobil merek Toyota beralih ke jasa kontraktor pembangunan jalan, bandara, dan pelabuhan.

Pengingkaran (Paragraf ke-6)

Haji Kalla, yang hanya seorang pengusaha dan bendahara "seumur hidup" Nahdlatul Ulama Cabang Makassar. (Paragraf ke-3 dari sub judul Bisnis keluarga)

(Stuktur Mikro) Kalimat pasif

Sintaksis Menurut catatan Komisi Pemberantasan Korupsi, kekayaan Kalla

Bentuk Kalimat dilaporkan pada 31 Mei 2007 tercatat sebesar Rp. 253,912 miliar dan 14.928 dolar AS. (Paragraf ke-4)

Jurnal Ilmu Komunikasi, Vol. 1, No.1, April 2011

ISSN: 2088-981X 
Tingkatan \& Elemen

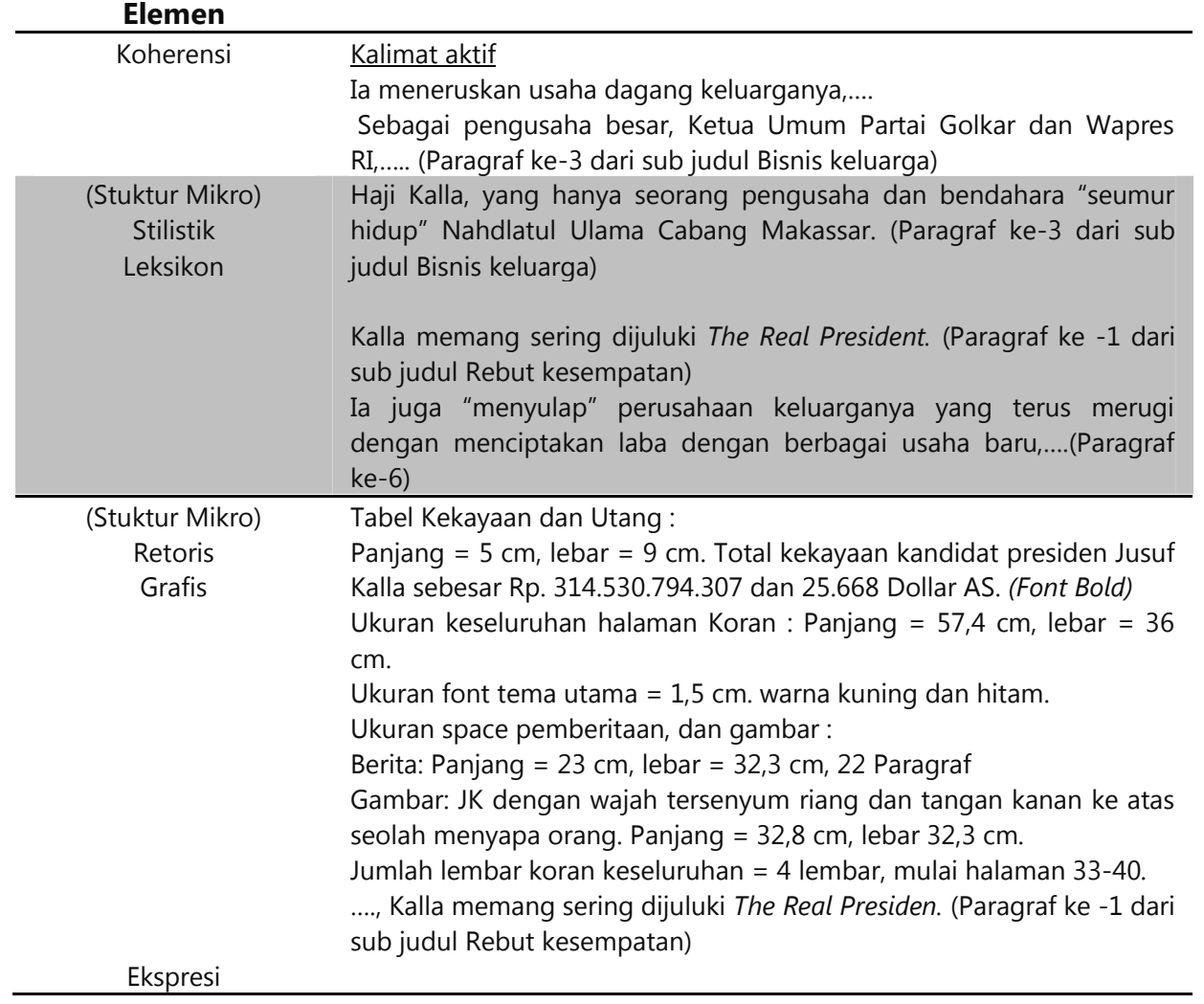

Pemberitaan ini lebih mengarah ke perjalanan karier keluarga Jusuf Kalla sehingga sampai menjadi saudagar sukses. Menjelaskan secara detail tentang perusahaan-perusahaan yang dikelola Jusuf Kalla, yang diperoleh melalui data Kompas. Jusuf Kalla berawal dari menjual komoditas kebutuhan sehari-hari sampai mengepakkan sayap membuka perusahaan di Jawa yaitu PT. Bukaka Teknik Utama yang memproduksi "belalai" penumpang untuk Bandara Soekarno Hatta.

Tabel 10

b. Judul: Muhammad Jusuf Kalla: Sang Saudagar di Pentas Politik (Penulis: Yohan Wahyu)

Tingkatan \&

Strategi Penulisan

Elemen

(Stuktur Makro) Judul: Sang Saudagar Dipentas Politik Tematik

(Superstuktur) Bentuk tulisan piramida terbalik, inti berita ada di atas kemudian Skematik mengalir dengan kronologis cerita. Summary: hidup Muhammad Jusuf Kalla yang kini popular dengan

Jurnal Ilmu Komunikasi, Vol. 1, No.1, April 2011

ISSN: 2088-981X 
Tingkatan \& Elemen

\section{Strategi Penulisan}

sebutan "JK" tidak bisa lepas dari dunia bisnis dan politik. Dua dunia itulah yang menempanya menjadi pribadi yang terbuka, tangkas dan sekaligus jeli. Kini, JK menjadi ikon baru sosok pengusaha di panggung politik nasional. Ia merupakan orang pertama dari kalangan saudagar yang duduk di kursi wakil presiden ke-10 yang pernah dimiliki Negara ini. (Lead)

Sub judul: Terjun di politik

Story: Antara karier pengusaha dan politik JK

Grafis Jejak Jusuf Kalla:

Grafis ini menjelaskan kronologis perjalanan Jusuf Kalla, mulai dari lahir 15 Mei 1942, sampai pada saat mendeklarasikan diri dengan Wiranto sebagai pasangan tanggal 1 Mei 2009.

Grafis Kiprah Jusuf Kalla:

Grafis ini merekam perjalanan karier JK beserta kontribusinya di pemerintahan, mulai dari pemerintahan Abdurrahman Wahid sampai menjadi wakil dari presiden SBY.

(Stuktur Mikro) Pasca menyandang gelar sarjana tahun 1967, putra Bugis ini tidak bisa Semantik Latar

Detail total langsung terjun ke politik meskipun sejak 1965 namanya tercatat sebagai Ketua Pemuda Sekber Golkar. Sejak lulus dari Unhas, ia harus menangani usaha warisan ayahnya. Melalui kepemimpinannya, pria yang kerap di panggil Daeng Ucu ini melakukan pembenahan roda bisnis milik keluarga tersebut,....(Paragraf ke-1)

Jusuf Kalla lahir di Watampone, Bone, Sulawesi Selatan, 15 Mei 1942.

Dunia politik sudah dirintisnya sejak menjadi mahasiswa Universitas Hasanuddin (Unhas), Makassar. Berbagai jabatan organisasi kemahasiswaan pernah disandangnya, dari Ketua Senat Mahasiswa Fakultas Ekonomi, Ketua Umum Himpunan Mahasiswa Islam Cabang Makassar, Ketua Dewan Mahasiswa Unhas, hingga Ketua Kesatuan

$\begin{array}{ll}\text { Maksud } & \text { Aksi Mahasiswa Indonesia Ujung Pandang. (Paragraf ke-1) } \\ & \text { Sepanjang mengurus bisnis keluarga tersebut, JK tidak melupakan }\end{array}$

Pra-anggapan dunia politik yang sudah digelutinya sejak mahasiswa. (Paragraf ke-5) Kini tantangan baru menghadang Jusuf Kalla. Ia akan menapaki jalur barunya ikut bersaing memperebutkan posisi puncak sebagai calon presiden. (Paragraf ke-4 dari sub judul Terjun di politik)

(Stuktur Mikro) Kalimat pasif Sintaksis

Bentuk Kalimat Kesuksesan dibidang bisnis mengantarkan JK sebagai saudagar yang diperhitungkan di kalangan pengusaha. (Paragraf ke-4)
Koherensi

Saat terjadi krisis politik dengan berakhirnya berakhirnya pemerintahan presiden Soeharto pada tahun 1998, Jusuf Kalla masih menjadi anggota MPR. Ketika Abdurrahman Wahid terpilih menjadi presiden, ia kemudian ditunjuk menjadi Menteri Perindustrian dan Perdagangan dalam Kabinet Persatuan Nasional. (Paragraf ke-2 dari sub judul Terjun di politik)

\begin{tabular}{cl}
$\begin{array}{c}\text { (Stuktur Mikro) } \\
\text { Stilistik }\end{array}$ & $\begin{array}{c}\text { Kini tantangan baru menghadang Jusuf Kalla. (Paragraf ke-4 dari sub } \\
\text { judul Terjun di politik) }\end{array}$ \\
\hline $\begin{array}{c}\text { Leksikon } \\
\text { (Stuktur Mikro) } \\
\text { Retoris }\end{array}$ & $\begin{array}{l}\text { Grafis Jejak Jusuf Kalla: } \\
\text { Panjang }=24 \mathrm{~cm}, \text { lebar }=16 \mathrm{~cm} .\end{array}$ \\
\hline
\end{tabular}

Jurnal Ilmu Komunikasi, Vol. 1, No.1, April 2011 
Tingkatan \&

Strategi Penulisan

Elemen

Grafis

Grafis Kiprah Jusuf Kalla:

Panjang $=7,8 \mathrm{~cm}$, lebar $=27 \mathrm{~cm}$.

Ukuran keseluruhan halaman Koran : Panjang $=57,4 \mathrm{~cm}$, lebar $=36$

$\mathrm{cm}$.

Ukuran font tema utama $=1,5 \mathrm{~cm}$, warna merah dan hitam.

Ukuran space pemberitaan, dan gambar:

Berita: panjang $=13 \mathrm{~cm}$, lebar $=16,5 \mathrm{~cm}$.

Gambar: JK mengacungkan jari telunjuk tangan kanan ke atas dengan memakai peci hitam, wajah serius, baju warna putih (gambar seperti lukisan atau karikatur), panjang $=43 \mathrm{~cm}$, lebar $23 \mathrm{~cm}$.

Pemberitaan ini masih seperti sebelumnya, lebih mengarah kepada sosok seorang Jusuf Kalla ketika menjalankan kiprah pengusaha dan politik. Tapi, berita ini lebih menonjolkan peran JK dalam mengemban amanah dari orang tuanya untuk melanjutkan bisnis keluarga setelah lulus dari kuliah. Menggambarkan JK yang aktif di beberapa organisasi selama menjadi mahasiswa dijelaskan secara detail. Setelah sukses di dunia bisnis JK menapaki jalur politik, karier politiknya mulai terbangun sejak menjadi perwakilan daerah di MPR dari Partai Golkar. (lihat tabel detail)

Tabel 11

c. Judul: Muhammad Jusuf Kalla: Dari Pengusaha Realistis

Menuju Pemimpin Progresif

(Penulis: Bagus Takwin, Niniek L Karim, Dicky Pelupessy, dan Nurlyta Hafiyah)

Tingkatan \&

Strategi Penulisan

Elemen

(Stuktur Makro) Judul: Muhammad Jusuf Kalla: Dari Pengusaha Realistis Menuju Tematik Pemimpin Progresif

(Superstuktur) Bentuk tulisan balok tegak

Skematik Summary: "Sekiranya ada keputusan wakil presiden, tentu semua kebijakan sudah saya ambil sehingga semuanya bisa berjalan dengan cepat dan lebih baik. Dengan demikian, krisis bisa segera kita selesaikan". (Lead)

Story: Kiprah JK di pemerintahan

Sub judul: Aspek kognitif: "trait" (sifat), "belief" (kepercayaan), kompleksitas pikiran, dan pola penalaran.

Sifat terbuka pad ide baru, disiplin ketat, logis, memanfaatkan waktu se-efisien mungkin, menilai tinggi ketangkasan dan kecepatan, kemauan untuk membaur dengan siapa saja, serta mau bekerja sama untuk mencapai keuntungan yang lebih besar menggerakkan Jusuf Kalla baik sebagai pebisnis maupun politikus.

Lepas dari dirinya, Jusuf Kalla dapat diandalkan sebagai pemimpin. (Sub lead)

Sub judul: Motif sosial

Jurnal Ilmu Komunikasi, Vol. 1, No.1, April 2011

ISSN: 2088-981X 
Tingkatan \& Elemen

\section{Strategi Penulisan}

Indikasi motif kekuasaan juga semakin menonjol pada penampilan diri Jusuf Kalla.

Sub judul: kepribadian dan kepemimpinan Jusuf Kalla

...., JK menunjukkan indikasi ciri kepemimpinan yang tampak menonjol: penuh inisiatif, awas terhadap situasi, cepat mengambil keputusan dan tanggap terhadap masalah, mampu mengambil tanggung jawab, mampu memantau jalannya penyelesaian masalah, dan mampu membuat strategi efektif.

(Stuktur Mikro) Kata-kata Jusuf Kalla yang dikutip Kompas.com, Kamis, 18 Juni 2009,

Semantik

Latar

Detail ini memberi petunjuk tentang inisiatifnya yang tinggi dan keinginan member pengaruh signifikan kepada lingkungannya. Dalam bisnis, ia adalah investor progresif. Di dunia politik, sifatnya dalam berbisnis ini juga tampil menonjol. (Paragraf ke-1)

Kemampuan mengolah sumber daya secara strategis menonjol pada Jusuf Kalla. Ia cepat dan efektif dalam mengambil keputusan serta selalu menghitung resiko. Kecenderungan berfikir satu langkah ke depan, kemampuan membina hubungan jangka panjang, dan mementingkan kemajuan juga menonjol pada dirinya. (Paragraf ke-2)

Maksud Karena sepak terjangnya yang gesit penuh inisiatif dalam mendampingi presiden SBY, banyak kalangan menilai ia berperan melebihi kapasitas wakil presiden sampai-sampai muncul sebutan the real president ditujukan pada dirinya. (Paragraf ke-10)

Pra-anggapan Lepas dari penampilan dirinya, Jusuf Kalla dapat diandalkan sebagai pemimpin. Seperti yang sudah dibuktikannya dalam bisnis dan pemerintahan,.... (Paragraf ke-6)

(Stuktur Mikro) Kalimat pasif

Sintaksis Kata-kata Jusuf Kalla yang dikutip Kompas.com, Kamis, 18 Juni

Bentuk Kalimat 2009,.....(Paragraf ke-1)

Koherensi Meskipun Jusuf Kalla senang berinteraksi dengan orang dan sering berada dalam situasi yang berubah-ubah, ia memperhatikan rincian rutin dalam kesehariannya. (Paragraf ke-5)

Sudah kami jelaskan pada pengantar, bicara motif sebaiknya kita gunakan teori motivasi dari McClelland yang menunjukkan tiga jenis kebutuhan. (kata ganti "kami" dan "kita"). (Paragraf ke-1 dari sub judul Motif sosial)

(Stuktur Mikro) _..., banyak kalangan menilai ia berperan melebihi kapasitas wakil Stilistik presiden sampai-sampai muncul sebutan the real president ditujukan Leksikon pada dirinya. (Paragraf ke-10)

(Stuktur Mikro) Retoris Grafis
Tabel Aspek Kepribadian yang Menonjol, Kekuatan dan Kelemahan Jusuf Kalla sebagai Pemimpin Politik :

Panjang $=10,5 \mathrm{~cm}$, lebar $=13,5 \mathrm{~cm}$.

Ukuran keseluruhan halaman Koran : Panjang $=57,4 \mathrm{~cm}$, lebar $=36$ $\mathrm{cm}$.

Ukuran font tema utama $=2 \mathrm{~cm}$, warna merah dan hitam.

Ukuran space pemberitaan, dan gambar:

Berita: panjang $=45 \mathrm{~cm}$, lebar $=32,3 \mathrm{~cm}$.

Gambar: JK tersenyum ringan dengan rambut rapi dan berbaju warna kecoklatan, Panjang $=31,5 \mathrm{~cm}$, lebar $20,5 \mathrm{~cm}$.

Jurnal Ilmu Komunikasi, Vol. 1, No.1, April 2011

ISSN: 2088-981X 
Pemberitaan tentang peranan JK selama menjadi wakil presiden, menonjolkan sifat-sifat baik yang dimiliki seorang Jusuf Kalla. Menjelaskan secara detail mengenai sifat gesit JK selama memimpin, sampai-sampai melebihi kapasitas seorang wakil presiden. Di dalam pemberitaan tersebut mengambil contoh kontribusi JK selama menjabat sebagai wakil presiden, adalah, JK mampu ikut menggagas, merencanakan, melaksanakan, dan mengawasi jalannya sebuah kebijakan atau program.

\section{Komparasi Konstruksi Wacana Harian Kompas Tentang Kandidat Presiden Pada Pemilihan Umum 2009}

a. Edisi 29, 30 Juni 2009 \& 1 Juli 2009

Tabel 12

\begin{tabular}{|c|c|c|c|}
\hline \multirow{3}{*}{ Elemen } & \multicolumn{3}{|c|}{ Strategi Penulisan } \\
\hline & Kandidat Mega (edisi & Kandidat SBY & Kandidat JK \\
\hline & 29 Juni 2009) & (edisi 30 Juni 2009) & (edisi 01 Juli 2009) \\
\hline 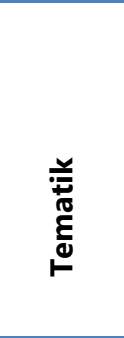 & $\begin{array}{l}\text { Megawati Soekarnoputri: } \\
\text { Menyusun Pertarungan } \\
\text { dari Bawah. } \\
\text { (Pengemasan font warna } \\
\text { merah sesuai dengan } \\
\text { lambang PDI-P dan } \\
\text { ukurannya } 1,5 \mathrm{~cm} \text { ). }\end{array}$ & $\begin{array}{l}\text { Susilo Bambang } \\
\text { Yudhoyono: Demokrasi } \\
\text { dan mimpi anak bangsa. } \\
\text { Pengemasan font warna } \\
\text { biru sesuai dengan } \\
\text { lambang Partai } \\
\text { Demokrat dan } \\
\text { ukurannya } 2 \mathrm{~cm} .\end{array}$ & $\begin{array}{l}\text { Muhammad Jusuf Kalla: } \\
\text { Sudah kaya, cari apa lagi?. } \\
\text { Judul yang mempunyai } \\
\text { kesan bahwa, JK yang sudah } \\
\text { kaya tidak boleh jadi } \\
\text { presiden. Pengemasan font } \\
\text { warna kuning sesuai dengan } \\
\text { lambang Partai Golkar, } \\
\text { ukurannya } 1,5 \mathrm{~cm} \text {. }\end{array}$ \\
\hline 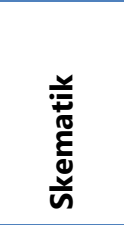 & $\begin{array}{l}\text { Terdapat dua lead, satu } \\
\text { sub judul, dan tabel } \\
\text { Kekayaan dan Hutang. }\end{array}$ & $\begin{array}{l}\text { Pada lead sudah } \\
\text { memberikan penilaian } \\
\text { baik pada SBY, terdapat } \\
\text { empat sub judul, dan } \\
\text { tabel Kekayaan dan } \\
\text { Hutang }\end{array}$ & $\begin{array}{l}\text { Terdapat tiga lead, lead } \\
\text { kedua berupa pertanyaan, } \\
\text { seputar JK yang sudah kaya } \\
\text { ingin menjadi presiden. } \\
\text { Terdapat dua sub judul. }\end{array}$ \\
\hline 冚 & $\begin{array}{l}\text { Strategi wartawan dalam } \\
\text { mengkonstruksi terlihat } \\
\text { dari, Latar: } \\
\text { Kekonsistenan Megawati } \\
\text { dalam ketika mendapat } \\
\text { ajakan berkoalisi. } \\
\text { Detail:Banyak } \\
\text { membicarakan tentang } \\
\text { kepribadian Megawati } \\
\text { yang negatif.memegang } \\
\text { amanat }\end{array}$ & $\begin{array}{l}\text { Strategi wartawan dalam } \\
\text { mengkonstruksi berita } \\
\text { terlihat dari, Latar: } \\
\text { menceritakan tentang } \\
\text { perjalanan SBY mulai } \\
\text { dari pendidikan. } \\
\text { Maksud:mengarahkan } \\
\text { kapada pembaca agar } \\
\text { apa yang sudah } \\
\text { dijalankan SBY ini patut } \\
\text { menjadi suri tauladan.. }\end{array}$ & $\begin{array}{l}\text { Strategi wartawan dalam } \\
\text { mengkonstruksi berita } \\
\text { terlihat dari, Latar: } \\
\text { Mengisahkan kesuksesan } \\
\text { keluarga JK menjadi } \\
\text { saudagar yang disegani. }\end{array}$ \\
\hline$\frac{\frac{n}{n}}{\frac{n}{5}}$ & $\begin{array}{l}\text { Bentuk kalimat pasif: } \\
\text { Megawati memang } \\
\text { kemudian berhasil } \\
\text { dilengserkan } \\
\text { pemerintah.... Koherensi }\end{array}$ & $\begin{array}{l}\text { Koherensi ditekankan } \\
\text { pada pertalian antara } \\
\text { kalimat dengan } \\
\text { proposisi, kata dengan } \\
\text { kata. }\end{array}$ & $\begin{array}{l}\text { Koherensi ditekankan pada } \\
\text { pertalian antara kalimat } \\
\text { dengan kalimat, kalimat } \\
\text { dengan proposisi }\end{array}$ \\
\hline
\end{tabular}

Jurnal Ilmu Komunikasi, Vol. 1, No.1, April 2011

ISSN: 2088-981X 


\begin{tabular}{|c|c|c|c|}
\hline \multirow[t]{2}{*}{ Elemen } & \multicolumn{3}{|c|}{ Strategi Penulisan } \\
\hline & $\begin{array}{l}\text { Kandidat Mega (edisi } \\
29 \text { Juni 2009) }\end{array}$ & $\begin{array}{c}\text { Kandidat SBY } \\
\text { (edisi } 30 \text { Juni 2009) }\end{array}$ & $\begin{array}{c}\text { Kandidat JK } \\
\text { (edisi } 01 \text { Juli 2009) }\end{array}$ \\
\hline & $\begin{array}{l}\text { ditekankan pada } \\
\text { pertalian antara kalimat } \\
\text { dengan kalimat, kata } \\
\text { dengan proposisi. Untuk } \\
\text { kata ganti menggunakan } \\
\text { "kita". }\end{array}$ & & \\
\hline 总 & $\begin{array}{l}\text { Pilihan kata yang } \\
\text { digunakan cenderung } \\
\text { mengarahkan ke arah } \\
\text { perlawanan dan } \\
\text { mempunyai kepribadian } \\
\text { negatif. }\end{array}$ & $\begin{array}{l}\text { Pilihan kata agak } \\
\text { menyentil, seperti kata } \\
\text { "diungsikan", tetapi } \\
\text { disitu menandakan } \\
\text { prestasi SBY yang } \\
\text { dipindah tugaskan } \\
\text { menjadi panglima } \\
\text { kodam. }\end{array}$ & $\begin{array}{l}\text { Pemilihan kata yang familiar } \\
\text { seperti julukan JK sebagai } \\
\text { The Real President. } \\
\text { Ungkapan itu tidak mampu } \\
\text { mengungguli kehebatan } \\
\text { SBY, nama SBY tidak } \\
\text { disinggung langsung ketika } \\
\text { menggunakan istilah the real } \\
\text { president buat JK. }\end{array}$ \\
\hline $\begin{array}{l}\stackrel{n}{\frac{n}{0}} \\
\stackrel{0}{0} \\
\stackrel{0}{\alpha}\end{array}$ & $\begin{array}{l}\text { Terdapat tabel kekayaan } \\
\text { dan hutang yang } \\
\text { mempunyai diameter } \\
5 \mathrm{~cm} \times 8,8 \mathrm{~cm} \text {. Juga } \\
\text { terdapat iklan di bawah } \\
\text { pemberitaan, itu } \\
\text { menjadikan kuantitas } \\
\text { pemberitaan dan } \\
\text { gambar berkurang. }\end{array}$ & $\begin{array}{l}\text { Terdapat tabel kekayaan } \\
\text { dan hutang yang } \\
\text { mempunyai diameter } \\
6 \mathrm{~cm} \text { x } 10.5 \mathrm{~cm} \text {. Tidak } \\
\text { terdapat iklan sama } \\
\text { sekali, membuat } \\
\text { kuantitas pemberitaan } \\
\text { dan gambar bebas satu } \\
\text { halaman penuh. }\end{array}$ & $\begin{array}{l}\text { Terdapat tabel kekayaan dan } \\
\text { hutang yang mempunyai } \\
\text { diameter } 5 \mathrm{~cm} \times 9 \mathrm{~cm} \text {. Tidak } \\
\text { terdapat iklan sama sekali, } \\
\text { membuat kuantitas } \\
\text { pemberitaan dan gambar } \\
\text { bebas satu halaman penuh. } \\
\text { Gambar berdiameter } 32.8 \mathrm{~cm} \\
\text { x } 32.3 \mathrm{~cm} \text {. }\end{array}$ \\
\hline
\end{tabular}

\section{b. Edisi 29, 30 Juni 2009 \& 1 Juli 2009 (Judul kedua pada halaman 34)}

Tabel 13

\begin{tabular}{|c|c|c|c|}
\hline \multirow[t]{2}{*}{ Elemen } & \multicolumn{3}{|c|}{ Strategi Penulisan } \\
\hline & $\begin{array}{c}\text { Kandidat Mega } \\
\text { (edisi } 29 \text { Juni 2009) }\end{array}$ & $\begin{array}{c}\text { Kandidat SBY } \\
\text { (edisi } 30 \text { Juni 2009) }\end{array}$ & $\begin{array}{c}\text { Kandidat JK } \\
\text { (edisi } 01 \text { Juli 2009) }\end{array}$ \\
\hline 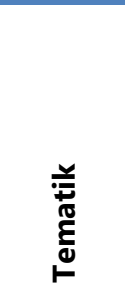 & $\begin{array}{l}\text { Megawati Soekarnoputri: } \\
\text { Bergerak pada masa } \\
\text { transisi bangsa. }\end{array}$ & $\begin{array}{l}\text { Susilo Bambang } \\
\text { Yudhoyono: Jenderal } \\
\text { "akademis" di panggung } \\
\text { politik. Pemilihan kata } \\
\text { akademis sudah } \\
\text { menandakan SBY adalah } \\
\text { orang yang pintar (aspek } \\
\text { positif). }\end{array}$ & $\begin{array}{l}\text { Muhammad Jusuf Kalla: } \\
\text { Sang saudagar di pentas } \\
\text { politik. }\end{array}$ \\
\hline 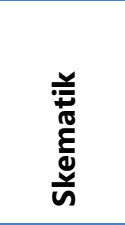 & $\begin{array}{l}\text { Bentuk tulisan piramida } \\
\text { terbalik. Terdapat lead, } \\
\text { ada dua grafis yang } \\
\text { menyebar di sekitar } \\
\text { gambar Megawati. Grafis } \\
\text { tersebut menceritakan }\end{array}$ & $\begin{array}{l}\text { Bentuk tulisan piramida } \\
\text { terbalik. Terdapat dua } \\
\text { lead, ada dua grafis di } \\
\text { bawah dan di atas } \\
\text { gambar SBY. Grafis yang } \\
\text { menjelaskan secara }\end{array}$ & $\begin{array}{l}\text { Bentuk tulisan piramida } \\
\text { terbalik. Terdapat dua lead, } \\
\text { satu sub judul. Ada dua } \\
\text { grafis di bawah dan samping } \\
\text { kiri gambar JK. }\end{array}$ \\
\hline
\end{tabular}

Jurnal Ilmu Komunikasi, Vol. 1, No.1, April 2011

ISSN: 2088-981X 


\begin{tabular}{|c|c|c|c|}
\hline \multirow[t]{3}{*}{ Elemen } & \multicolumn{3}{|c|}{ Strategi Penulisan } \\
\hline & $\begin{array}{c}\text { Kandidat Mega } \\
\text { (edisi } 29 \text { Juni 2009) }\end{array}$ & $\begin{array}{c}\text { Kandidat SBY } \\
\text { (edisi } 30 \text { Juni 2009) }\end{array}$ & $\begin{array}{c}\text { Kandidat JK } \\
\text { (edisi } 01 \text { Juli 2009) }\end{array}$ \\
\hline & rekam jejak Megawati. & $\begin{array}{l}\text { detail perjalanan SBY } \\
\text { mulai lahir sampai } \\
\text { deklarasi calon presiden } \\
\text { dengan Boediono } \\
\text { sebagai wakilnya. }\end{array}$ & \\
\hline 言 & $\begin{array}{l}\text { Strategi wartawan dalam } \\
\text { mengkonstruksi terlihat } \\
\text { dari, Pengingkaran: } \\
\text { Megawati menjual aset } \\
\text { negara selama menjadi } \\
\text { presiden. Itu bertanda } \\
\text { ada kesengajaan } \\
\text { wartawan dalam } \\
\text { mengarahkan jalannya } \\
\text { berita }\end{array}$ & $\begin{array}{l}\text { Strategi wartawan dalam } \\
\text { mengkonstruksi berita } \\
\text { terlihat dari, Latar: } \\
\text { Menjelaskan tentang } \\
\text { kewibawaan seorang } \\
\text { SBY ketika menghadapi } \\
\text { masyarakat. Sangat } \\
\text { detail dalam } \\
\text { mengungkapkan } \\
\text { kelebihan yang dimiliki } \\
\text { SBY. }\end{array}$ & $\begin{array}{l}\text { Strategi wartawan dalam } \\
\text { mengkonstruksi berita } \\
\text { terlihat dari, Maksud: } \\
\text { kesuksesan di bidang bisnis } \\
\text { mengantarkan JK sebagai } \\
\text { saudagar yang } \\
\text { diperhitungkan di kalangan } \\
\text { pengusaha. }\end{array}$ \\
\hline 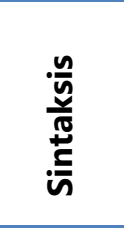 & $\begin{array}{l}\text { Koherensi lebih kepada } \\
\text { pertalian antara kalimat } \\
\text { dengan kalimat. }\end{array}$ & $\begin{array}{l}\text { Koherensi lebih kepada } \\
\text { pertalian antara kalimat } \\
\text { dengan kalimat, kalimat } \\
\text { dengan proposisi. }\end{array}$ & $\begin{array}{l}\text { Kalimat pasif: ...saudagar } \\
\text { yang diperhitungkan } \\
\text { dikalangan pengusaha. } \\
\text { Koherensi lebih pada } \\
\text { pertalian antara kalimat } \\
\text { dengan kalimat. }\end{array}$ \\
\hline 兰 & $\begin{array}{l}\text { Pilihan kata sangat } \\
\text { persuasif dengan } \\
\text { menonjolkan karakter } \\
\text { negatif Megawati. }\end{array}$ & $\begin{array}{l}\text { Pilihan kata sangat } \\
\text { persuasif dengan } \\
\text { mengungkap secara } \\
\text { detail kelebihan SBY.. }\end{array}$ & $\begin{array}{l}\text { Pemilihan kata yang } \\
\text { menyudutkan, seperti kini } \\
\text { tantangan baru } \\
\text { menghadang... }\end{array}$ \\
\hline 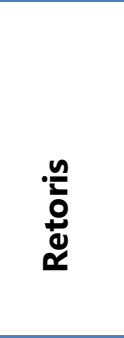 & $\begin{array}{l}\text { Terdapat grafis dua yang } \\
\text { berwarna merah. dan } \\
\text { juga terdapat iklan di } \\
\text { bawah pemberitaan, itu } \\
\text { menjadikan kuantitas } \\
\text { pemberitaan dan } \\
\text { gambar berkurang. } \\
\text { Diameter gambar } \\
24.5 \mathrm{~cm} \times 25.5 \mathrm{~cm} \text {. }\end{array}$ & $\begin{array}{l}\text { Terdapat grafis dua yang } \\
\text { berwarna biru. gambar } \\
\text { lebih besar dengan } \\
\text { diameter } 34.5 \mathrm{~cm} \mathrm{x} \\
28.5 \mathrm{~cm} .\end{array}$ & $\begin{array}{l}\text { Terdapat grafis dua yang } \\
\text { berwarna kuning. Gambar } \\
\text { berdiameter } 42 \mathrm{~cm} \mathrm{x} 23 \mathrm{~cm} \text {. }\end{array}$ \\
\hline
\end{tabular}

Jurnal Ilmu Komunikasi, Vol. 1, No.1, April 2011

ISSN: 2088-981X 
c. Edisi 29, 30 Juni 2009 \& 1 Juli 2009 (Judul ketiga pada halaman 35)

Tabel 4.17

\begin{tabular}{|c|c|c|c|}
\hline Elemen & $\begin{array}{l}\text { Kandidat Mega (edisi } \\
29 \text { Juni 2009) }\end{array}$ & $\begin{array}{c}\text { Strategi Penulisan } \\
\text { Kandidat SBY } \\
\text { (edisi } 30 \text { Juni 2009) }\end{array}$ & $\begin{array}{c}\text { Kandidat JK } \\
\text { (edisi } 01 \text { Juli 2009) }\end{array}$ \\
\hline 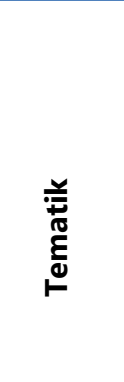 & $\begin{array}{l}\text { Putri proklamator yang } \\
\text { berjuang dengan } \\
\text { kekerasan hati. Dari } \\
\text { judul sudah kelihatan } \\
\text { makna kekerasan disini } \\
\text { diartikan Megawati } \\
\text { berhasrat untuk } \\
\text { berkuasa. }\end{array}$ & $\begin{array}{l}\text { Susilo Bambang } \\
\text { Yudhoyono: Berjuang } \\
\text { menjadi pahlawan. } \\
\text { Pemilihan kata } \\
\text { pahlawan, sudah pasti } \\
\text { menandakan SBY } \\
\text { sebagai sosok pahlawan } \\
\text { (aspek positif). Ukuran } \\
\text { font judul PAHLAWAN } \\
\text { 2cm dengan warna biru. }\end{array}$ & $\begin{array}{l}\text { Muhammad Jusuf Kalla: Dari } \\
\text { pengusaha realistis menuju } \\
\text { pemimpin progresif. Ukuran } \\
\text { font kata PROGRESIF } 2 \mathrm{~cm} \\
\text { dengan warna hitam. }\end{array}$ \\
\hline 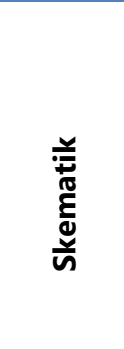 & $\begin{array}{l}\text { Bentuk tulisan balok } \\
\text { tegak. Leadnya sudah } \\
\text { langsung mengarah } \\
\text { pada sosok penyerang } \\
\text { Megawati. Terdapat satu } \\
\text { tebel kepribadian, dan } \\
\text { ada } 4 \text { sub judul. }\end{array}$ & $\begin{array}{l}\text { Bentuk tulisan balok } \\
\text { tegak. Terdapat dua } \\
\text { lead, dan lead utama } \\
\text { mengarah pada } \\
\text { penilaian charming } \\
\text { kepada sosok SBY. } \\
\text { Terdapat satu tabel } \\
\text { kepribadian, dan ada } 4 \\
\text { sub judul. }\end{array}$ & $\begin{array}{l}\text { Bentuk tulisan balok tegak. } \\
\text { Terdapat dua lead, lead } \\
\text { utama mengarah kepada } \\
\text { pencitraan kepribadian gesit } \\
\text { JK. Terdapat satu tabel } \\
\text { kepribadian, dan ada } 4 \text { sub } \\
\text { judul. }\end{array}$ \\
\hline ڤ̆ & $\begin{array}{l}\text { Strategi wartawan dalam } \\
\text { mengkonstruksi berita } \\
\text { terlihat dari, Latar: } \\
\text { Megawati adalah pribadi } \\
\text { yang kompleks dan sulit } \\
\text { dipahami...memberikan } \\
\text { penilaian karakter } \\
\text { negatif kepada } \\
\text { Megawati. Tulisan ini } \\
\text { mengurai tentang } \\
\text { kepribadian anak kedua } \\
\text { atau tengah, dengan } \\
\text { menggunakan teori } \\
\text { psikoanalisis. }\end{array}$ & $\begin{array}{l}\text { Strategi wartawan dalam } \\
\text { mengkonstruksi berita } \\
\text { terlihat dari, Latar: } \\
\text { Memberikan penilaian, } \\
\text { apakah SBY sedang } \\
\text { berjuang menjadi } \\
\text { pahlawan?. Penonjolan } \\
\text { majalah Time Asia dalam } \\
\text { tulisan (Paragraf 10), } \\
\text { menambah kelebihan } \\
\text { SBY dimata masyarakat. } \\
\text { Tanpa harus mengurai } \\
\text { tentang kepribadian di } \\
\text { nilai dari nomer urut } \\
\text { kelahiran anak, seperti } \\
\text { yang terlihat jelas pada } \\
\text { pemberitaan Megawati. }\end{array}$ & $\begin{array}{l}\text { Strategi wartawan dalam } \\
\text { mengkonstruksi berita } \\
\text { terlihat dari, Latar: Pengaruh } \\
\text { JK yang gesit dan pintar } \\
\text { pada lingkungan. Tanpa } \\
\text { harus mengurai tentang } \\
\text { kepribadian di nilai dari } \\
\text { nomer urut kelahiran anak, } \\
\text { seperti yang terlihat jelas } \\
\text { pada pemberitaan } \\
\text { Megawati. Melainkan } \\
\text { mengurai tentang motif } \\
\text { sosial, diperkuat dengan } \\
\text { teori motivasi. }\end{array}$ \\
\hline$\frac{\frac{n}{n}}{\frac{n}{5}}$ & $\begin{array}{l}\text { Koherensi lebih kepada } \\
\text { pertalian antara kalimat } \\
\text { dengan kalimat, kalimat } \\
\text { dengan proposisi. Kata } \\
\text { ganti "kami" dan "kita". }\end{array}$ & $\begin{array}{l}\text { Pertalian antara kalimat } \\
\text { dengan kalimat, kalimat } \\
\text { dengan proposisi. Kata } \\
\text { ganti "kami" (institusi } \\
\text { Kompas). }\end{array}$ & $\begin{array}{l}\text { Pertalian antara kalimat } \\
\text { dengan kalimat, kalimat } \\
\text { dengan proposisi. Kata ganti } \\
\text { "kami" (institusi Kompas). }\end{array}$ \\
\hline
\end{tabular}

Jurnal Ilmu Komunikasi, Vol. 1, No.1, April 2011

ISSN: 2088-981X 


\begin{tabular}{|c|c|c|c|}
\hline \multirow[t]{2}{*}{ Elemen } & \multicolumn{3}{|c|}{ Strategi Penulisan } \\
\hline & $\begin{array}{l}\text { Kandidat Mega (edisi } \\
29 \text { Juni 2009) }\end{array}$ & $\begin{array}{c}\text { Kandidat SBY } \\
\text { (edisi } 30 \text { Juni 2009) }\end{array}$ & $\begin{array}{c}\text { Kandidat JK } \\
\text { (edisi } 01 \text { Juli 2009) }\end{array}$ \\
\hline 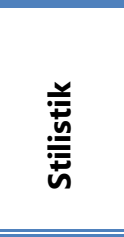 & $\begin{array}{l}\text { Pilihan kata sangat } \\
\text { persuasif dengan } \\
\text { menonjolkan karakter } \\
\text { negatif Megawati. }\end{array}$ & $\begin{array}{l}\text { Pilihan kata mengarah } \\
\text { kepada kepribadian } \\
\text { yang tangguh, seperti } \\
\text { pada pilihan kata } \\
\text { "pedang } \\
\text { kepemimpinan". } \\
\end{array}$ & $\begin{array}{l}\text { Pemilihan kata lebih alami, } \\
\text { tanpa ada sesuatu yang } \\
\text { ditonjolkan. Hanya kata the } \\
\text { real presiden saja. }\end{array}$ \\
\hline $\begin{array}{l}\stackrel{n}{\frac{n}{0}} \\
\stackrel{0}{0} \\
\stackrel{0}{\alpha}\end{array}$ & $\begin{array}{l}\text { Terdapat tabel } \\
\text { kepribadian, dan juga } \\
\text { terdapat iklan di bawah } \\
\text { pemberitaan, itu } \\
\text { menjadikan kuantitas } \\
\text { pemberitaan dan } \\
\text { gambar berkurang. } \\
\text { Gambar berdiameter } \\
20 \mathrm{~cm} \times 14.5 \mathrm{~cm} .\end{array}$ & $\begin{array}{l}\text { Terdapat tabel } \\
\text { kepribadian, gambar } \\
\text { mempunyai diameter } \\
24.5 \mathrm{~cm} \times 15 \mathrm{~cm} \text { cukup } \\
\text { besar dibanding ukuran } \\
\text { gambar Megawati. }\end{array}$ & $\begin{array}{l}\text { Terdapat tabel kepribadian, } \\
\text { gambar mempunyai } \\
\text { diameter } 31.5 \mathrm{~cm} \times 20.5 \mathrm{~cm} \\
\text { cukup besar dibanding } \\
\text { ukuran gambar Megawati } \\
\text { dan SBY. }\end{array}$ \\
\hline
\end{tabular}

\section{Temuan Penelitian}

Dalam analisis data di atas didapatkan beberapa temuan antara lain:

a) Terdapat perbedaan strategi pemilihan kata oleh wartawan dalam penulisan judul di masing-masing kandidat.

b) Adanya keberpihakan dalam pemberitaan, kandidat presiden Susilo Bambang Yudhoyono di unggul-unggulkan daripada kandidat presiden Megawati dan Jusuf Kalla.

c) Terdapat strategi wartawan dalam mempengaruhi pembaca aktif, melalui pemberian gambaran jelas tentang rekam jejak dari masingmasing kandidat, terlepas dari baik atau buruk.

d) Dalam penggunaan space halaman juga sangat berbeda sekali, hanya kandidat Megawati yang terdapat iklan. Itu bisa mengurangi kuantitas pemberitaan.

\section{Penutup} berikut:

Dari paparan hasil penelitian di atas maka dapat disimpulkan sebagai

1. Struktur Makro, wacana pemberitaan mengarah kepada kepribadian, kelemahan, dan kelebihan dari masing-masing kandidat presiden.

2. Superstruktur, skema pemberitaan dari ketiga kandidat hampir sama. Kebanyakan menggunakan bentuk tulisan balok tegak, inti berita menyebar tidak fokus pada paragraf tertentu saja. Diungkap melalui tulisan tanya jawab terlebih dahulu, baru pendapat wartawan masuk diperkuat dengan data dari Kompas dan juga teori yang relevan.

Jurnal Ilmu Komunikasi, Vol. 1, No.1, April 2011

ISSN: 2088-981X 
3. Struktur Mikro, penggunaan kata sangat kelihatan keberpihakan wartawan dalam pemberitaan. Dalam hal ini pemberitaan kandidat Megawati sangat terpojokkan, dengan memperbanyak ungkapan negatif tentang diri Megawati. Untuk penggunaan kata ganti juga banyak menggunakan kata ganti "kami" sebagai representasi dari institusi Kompas sebagai lembaga sang wartawan bekerja.

4. Perbandingan penyajian berita yang paling mendasar adalah letak pemberian space halaman yang tidak sesuai atau tidak adil dari masingmasing kandidat. Itu terlihat sangat jelas pada kandidat presiden Megawati yang hanya diberi space berita berdiameter panjang $26,8 \mathrm{~cm}$ dengan lebar halaman $32,3 \mathrm{~cm}$. Ukuran total satu halaman koran $57,4 \mathrm{~cm} \times 36 \mathrm{~cm}$. Terkikis oleh iklan sebesar $15 \mathrm{~cm}$, lebar $=23$. Itu menandakan kuantitas dari pemberitaan profil Kandidat Megawati menjadi terkurangi. Sedangkan kandidat presiden SBY dan JK masing-masing diberi leluasa, tanpa ada hambatan iklan.

\section{Daftar Pustaka}

Rais, Amien, 2008, Agenda Mendesak Bangsa: Selamatkan Indonesia, PPSK Press, Yogjakarta

Pawito, 2009, Komunikasi Politik: Media Massa dan Kampanye Pemilihan, Jalasutra, Yogyakarta.

Titscher, Stefan dkk, 2009, Metode Analisis Teks dan Wacana, Terjemahan oleh Gazali, Thomas Pandonge dkk, Pustaka Pelajar, Yogyakarta.

Eriyanto, 2006, Analisis Wacana: Pengantar Analisis Teks Media, LKIS, Yogyakarta.

Hamad, Ibnu, 2008, Media dan Demokrasi di Asia Tenggara: Kasus Indonesia, Universitas Indonesia, Jakarta.

Sobur, Alex, 2006, Analisis Teks Media: Suatu Pengantar untuk Analisis Wacana, Analisis Semiotik, dan Analisis Framing, PT. Remaja Rosda Karya, Bandung. 